\author{
WILLIAM E. GIBSON
}

Brookings Institution

\title{
Protecting Homebuilding from Restrictive Credit Conditions
}

THE PRODUCTION OF NEW HOUSING is a credit-intensive process in the United States and in other industrial countries. The homebuilding industry is a relatively heavy user of credit in its production process, and housing units, from which the services flow, are normally purchased with long-term credits-appropriately enough, since they are among the longest-lived assets in the economy. This practice and the institutional framework of housing finance in the United States have made the industry vulnerable to variations in credit market conditions, particularly during periods of intense monetary restraint. Although substantial federal efforts have been undertaken to offset this vulnerability, the experiences of housing in 1966, 1969-70, and 1973, when homebuilding declined dramatically, amply demonstrate it.

Virtually no observer would argue that there is no relationship between interest rates and homebuilding (although there is disagreement on precisely how the relationship operates); but there are widely different views on its value to the economy. At one extreme, the response of housing to restrictive monetary policy is regarded as a severe evil to the economy and to society. The argument goes on several levels. On the first, the principle that any increase in housing production is a good thing is taken as selfevident. From there it is an easy jump to the corollary that any decrease is

Note: I am very happy to acknowledge the helpful assistance provided by Andrew Carron and the valuable suggestions of members of the Brookings panel. 
a bad thing. Although this view-which implies that even a slight retreat from a record level of housing production should be avoided-has few strict-constructionist adherents, the concern that the nation not drift far from a steady path toward its housing goals is a pervasive one. On another level of the argument, housing should do no more than "its part" in assisting restraint during times of high interest rates. Up to now, however, it has been rare to find proponents of this view advocating limits on the benefits to housing from abundant flows of funds when credit markets eased.

The other main line of argument for protecting housing from the effects of restrictive policy deals with the impact on the supply of homebuilders. Extreme variations in the output of any industry, ceteris paribus, should tend to discourage investment in it. If homebuilders are driven out of the industry by a severe drop in housing funds and production, they will likely require higher profits, and as a result higher home prices, to return. If the nation is to meet its housing production goals, it needs a large, "strong," homebuilding industry, not one that is periodically decimated by credit crunches.

At the opposite pole, the interest sensitivity of housing is welcomed as a helpful countercyclical influence. Holders of this view note that during cyclical expansions, most components of aggregate demand expand together. While many, if not all, are sensitive to interest rate fluctuations, they also tend to be positively related to the level of economic activity. The depressing effect of rising interest rates is therefore more than offset by the positive influence of income and expectations. Housing is one of the few categories of spending, if not the only one, for which the interest rate effect dominates, making it a natural stabilizing force. In this regard, Arnold Harberger has described this aspect of housing fluctuation as similar to the operation of a sponge:

... Historically the construction industry has been what I call the handmaiden of monetary policy. When monetary policy is tight, the construction industry is squeezed. The purpose of tight monetary policy is to free resources ... and that squeeze takes place largely by pushing resources out of the construction industry. And, when monetary policy is easy, somehow the resources crawl out of the woodwork to allow housing starts to go up by three or four hundred thousand. ...

Now, because the housing industry has acted as a sponge, absorbing resources when money is easy and releasing them when it is tight, I have always been very skeptical of the idea ... that our government should have a set of housing goals which would try to get a given number of housing starts per year and keep hous- 
ing on a certain preset track. That is, in my view, the easiest conceivable way of emasculating monetary policy.

... I am disturbed that so much ... discussion ... reflects a preoccupation that our tight monetary policy has hurt housing. I'm not worried by this. Quite to the contrary, I think that I'd be worried if housing were not being squeezed, because then the tight monetary policy would not be having its desired effect. I think that in the other areas in which monetary policy can affect real spending it is much less powerful than it is in housing, and we have got to continue to allow tight monetary policy to squeeze housing, and easy monetary policy to stimulate housing, if we are going to have an effective fine-tuning or short-run stabilizing policy tool in our kit. ${ }^{1}$

Since there are few such forces in the private sector, the argument goes, this response by housing should not be impeded. Some would carry the argument even further and favor accentuating the contraction of homebuilding activity during an expansion by way of such measures as interest ceilings on government-insured mortgages and on deposits in thrift institutions, and other nonmarket means of disrupting the flow of funds to housing when interest rates are rising. These two opposing arguments seldom confront one another directly even though in principle they can and should.

\section{Government Involvement in Housing}

In many nations housing has long been an area of government interest and activity. In the United States the involvement began with the treatment of interest and housing services in the income tax system and with mortgage insurance programs of the Federal Housing Administration in the 1930s, and it has increased markedly since the Housing and Urban Development Act of 1968. Government housing support programs here and abroad doubtless owe their existence mostly to their political appeal, but economic rationales have been advanced as well. The most important is that externalities derive from a well-housed population. A portion of the benefits of a well-maintained house go to one's neighbors-a well-painted house or a handsome lawn, for instance. There is also a pervasive view that homeowners tend to be good citizens with a meaningful stake in their society. This is an externality as well and is difficult to quantify. It seems, however,

1. Arnold C. Harberger, "Discussion," in Housing and Monetary Policy, Proceedings of the Monetary Conference, 1970 (Federal Reserve Bank of Boston, 1970), p. 37. 
to play a role in the political attachment to housing, ${ }^{2}$ even though government housing programs also provide considerable incentives to build rental units.

Government aid to the mortgage market might also be advocated in order to provide a pooling of risks that would not generally take place otherwise. The comparison of the interest rates on loans to buy homes with those on loans to buy machine tools is instructive. Without U.S. institutional benefits to the mortgage market, rates on equipment would be lower than housing rates, and have in fact generally been so anyway. They are not lower because the collateral is superior, although as a practical matter the value of a house as security for a lender is lessened by the legal proceedings and delays entailed in laws protecting homeowners and occupants from unreasonable repossession and eviction.

The more important reason for the rate divergence is probably that lenders value the signature of a machine tool buyer such as General Motors Corporation more highly than a homebuyer's. The machine tool buyer is thus in effect pooling risks and securing a better interest rate as a result. A homebuyer typically cannot do this. Private institutions could engage in such risk pooling, and real estate investment trusts might be viewed as serving this function. It requires the detailed information about real estate markets that a savings and loan association might have. But against the economies of scale of information in a particular area must be balanced the need for diversification to protect against the possibility that the entire local real estate market will erode relative to the national average. Government efforts might therefore be directed at pooling these private risks so that housing can borrow at rates reflecting the social risks of default.

While these grounds support governmental intervention in housing, they do not imply that such aid should be greater when interest rates are higher. The same average amount of long-run support to mortgage and housing markets could be provided with wider-or narrower-fluctuations in volume than now. Wide fluctuations around a trend line do not by themselves nullify the trend. If the effects of monetary policy are symmetrical, the sensitivity of homebuilding to credit conditions would not conflict with national housing goals nor with any particular social priority for housing over the long run.

2. For instance, President Johnson established the Kerner Commission to study the nation's housing problems largely in response to the summer urban riots of the late 1960s. See the Report of the National Advisory Commission on Civil Disorders (1968). 
It is difficult to see why the divergence between social and private benefits should be greater the higher the level of rates. The justification for governmental intervention would be a reinforcement of the interest rate response of housing by a systematic tendency, arising from institutional causes, to squeeze housing out of credit markets on nonprice grounds. This case has been made with considerable force in the United States along two lines. The first views banks as increasing, when credit conditions tighten, the proportion of funds lent to businesses as implicit interest on demand deposit balances that had been held when rates were lower. ${ }^{3}$ To the extent that this happens, it is primarily the result of the prohibition of explicit interest payments on demand deposits since 1933.

Lending for housing also tends to be disrupted when rates rise because the institutions established to provide such lending-savings and loan associations and mutual savings banks-become severely constrained in their ability to attract funds. Thrift institutions are strongly encouraged by regulations and tax law to borrow short and lend long. The earnings of their portfolios therefore adjust only slowly to changes in market rates, while yields on alternatives to their time deposits-such as Treasury bills and federal agency securities-move with the market. When faced with a steep rise in interest rates, thrift institutions are often unable to pay enough interest out of current earnings to retain their deposits, much less attract net new funds. If there were no trend in rates, these institutions could draw on reserves to pay higher yields and replenish them by reducing interest when market rates fell. Thrift institutions seem to have a general aversion to this averaging, and in recent years they would probably have been right, for interest rates have been on a general upward trend since 1952. While other lenders could move in to fill the void, they typically do not entirely do so in the short run.

Lending arrangements at institutions may also make mortgage rates slow to move when market rates are rising, so that fewer funds reach the mortgage market than if yields were determined by open outcry. Thrift institutions and banks are understandably interested in developing and maintaining long-term relationships with both customers and builders. Builders in particular offer prospects of continuing mortgage business, so that thrift

3. See Lester C. Thurow, "Proposals for Rechanneling Funds to Meet Social Priorities," in Policies for a More Competitive Financial System: A Review of the Report of the President's Commission on Financial Structure and Regulation, Proceedings of a Conference, 1972 (Federal Reserve Bank of Boston, 1972). 
institutions tend to make commitments to lend to them, either formal or informal, that they are hesitant to go back on. The commitment often provides that the rate at which the loans are made will not be raised when other rates rise. Since thrift institutions account for such an important portion of the residential mortgage market (68.1 percent of the mortgages made in 1972), this reluctance to abrogate commitments even in the face of a rise in overall rates may depress mortgage rates generally, making the market less attractive to diversified lenders such as insurance companies and commercial banks. As a result, when interest rates generally are high homebuilding may receive less funds than they would were rates determined in the open market.

Finally, one might argue that housing merits special assistance when interest rates rise because the government should protect those hurt by its mistakes. This argument holds that broad swings in rates are necessitated by inadequate earlier monetary and fiscal policies. It seems to be a partial justification for federal insurance of funds at depository institutions, since their rate of failure tends to be higher when the economy is subjected to sharply restrictive monetary policy. Such a view may have influenced Congress in establishing federal housing programs. Its logical extension would shelter every borrower from the effects of high rates and would compromise the effectiveness of monetary policy.

\section{Housing Production and Gross National Product}

Empirically, housing has been one of the most stabilizing types of spending and production in the economy. Table 1 gives correlations between

Table 1. Correlations of Nominal and Real Gross National Product, by Major Components, Quarterly, 1947:1 to 1973:2

\begin{tabular}{lcc}
\hline \multicolumn{1}{c}{ Component } & Nominal GNP & Real GNP \\
\hline Investment in residential structures & 0.913 & 0.690 \\
Durable goods consumption expenditures & 0.995 & 0.982 \\
Nondurable goods consumption expenditures & 0.999 & 0.997 \\
Services consumption expenditures & 0.999 & 0.996 \\
Investment in nonresidential structures & 0.995 & 0.954 \\
Producers' durable equipment & 0.992 & 0.965 \\
Government purchases & 0.995 & 0.949 \\
Net change in business inventories & 0.348 & 0.347 \\
Net exports of goods and services & -0.414 & -0.470 \\
\hline
\end{tabular}

Sources: Survey of Current Business, various issues, and U.S. Office of Business Economics, The National Income and Product Accounts of the United States, 1929-1965: Statistical Tables (1966). 
nominal and real gross national product and its components from 1947 to 1973. Of the first six components, the correlations of residential construction with GNP are the lowest. The difference between real construction and other real components is especially great.

Even for real construction, however, the correlation is strongly positive, reflecting the marked upward trend in both series. From 1947 to 1972, the correlation between housing starts and real GNP was 0.317 , and between starts and nominal GNP, 0.394. In terms of deviations from a twelve-quarter trend, however, the correlations for housing are lower: that between real residential construction expenditures and real GNP for 1948-71 is 0.378 , and that between housing starts and real GNP is 0.100 . Thus while the relationship between housing construction and GNP is not negative, it is considerably lower than those for other components. And housing doubtless has exerted a moderating force as a result of its tendency to peak midway in an upswing.

The correlations of Table 1 are not fully relevant to considering whether housing has in fact countered the business cycle because they are not adjusted for cyclical influences. Table 2 attempts to remedy this by relating real sector shares to the proportional GNP gap and a time trend. The coefficient in the residential construction equation is significantly positive, indicating that the share of homebuilding increases the further real GNP moves below potential. In this sense, homebuilding plays a countercyclical role. Table 2 also identifies the other sectors that tend to move against the cycle-consumption of nondurables and of services, and the net export balance. The first two display a much stronger countercyclical influence than residential construction, but since they do not involve durable goods they are unlikely to be responsive to changes in interest rates (though this does not rule out a more direct influence of monetary changes on these forms of spending). In addition the other sectors producing durable goods - consumer durables, nonresidential construction, and producers' durables-are either unrelated to the GNP gap or negatively related (with a statistically significant negative relation for producers' durables). Residential construction is thus the only durables sector that has acted as a stabilizer.

\section{Interest Sensitivity of Housing and Homebuilding}

Since housing units are among the longest-lived assets in the economy, credit plays a very important role in their production and purchase. Some 


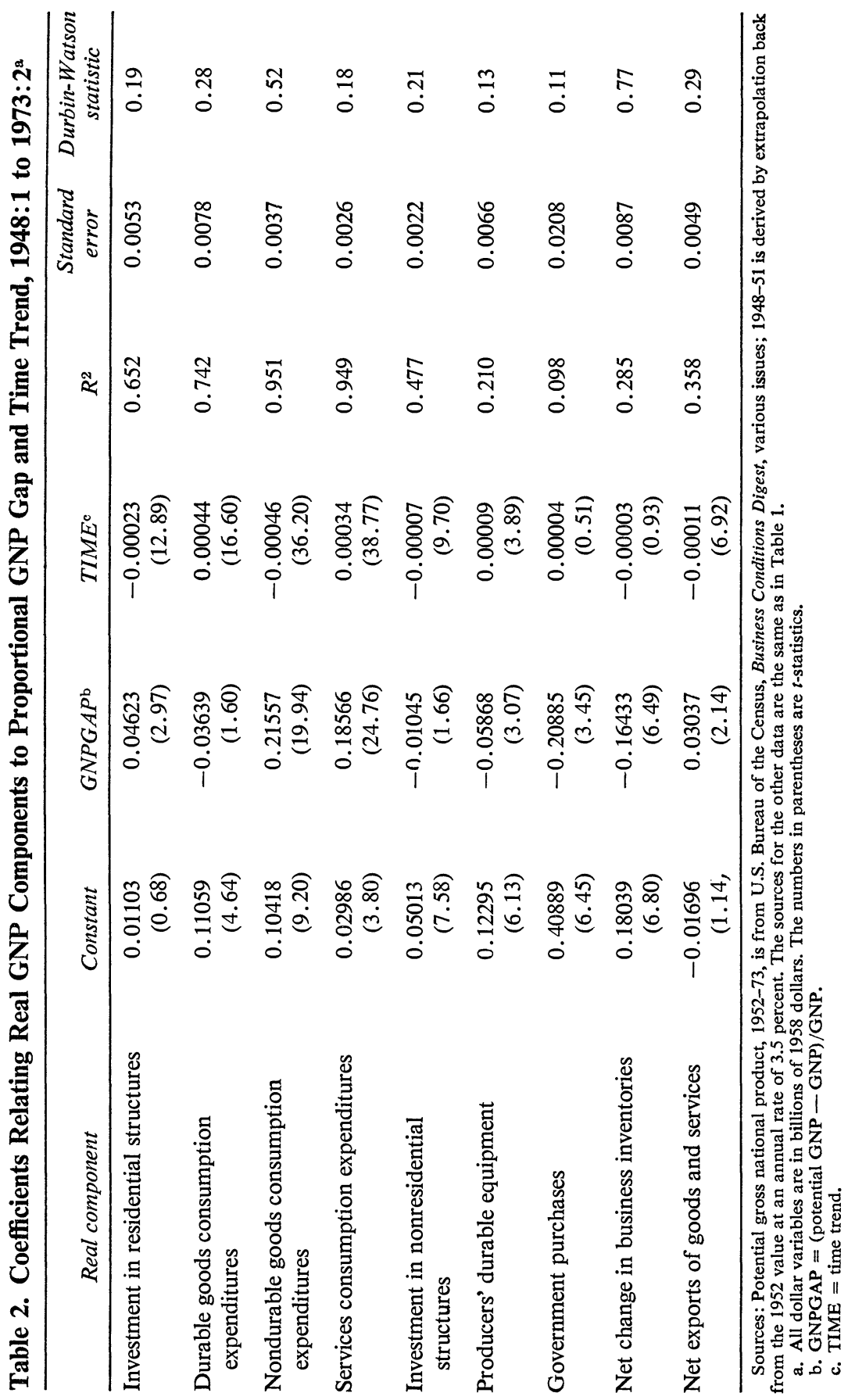


homebuyers make downpayments of as low as 10,5 , or nearly zero percent. Rising interest rates can depress homebuilding in two ways. First, since houses are among the most durable assets in the economy, increases in interest rates mean that the future services of houses are discounted at a higher rate so that houses are less valuable. As a result, fewer houses are demanded at going prices, and homebuilding is depressed. Although the effect is frequently overlooked, rising interest rates also squeeze homebuilding by raising the costs of construction loans, working capital of builders, and trade credit supplied to the construction industry. Second, conventional wisdom asserts that the demand for houses also depends on the cost and availability of mortgage funds. ${ }^{4}$ This wisdom holds that homebuilding has responded not simply to changes in interest rates in general but also to rates on mortgage loans in particular and to the availability of funds from traditional mortgage lenders, such as savings and loan associations and mutual savings banks.

The view that the cost of mortgage credit, separate from general trends in market interest rates, influences homebuilding assumes that there are few substitutes for mortgage credit in financing houses and that mortgage credit is by and large used only to finance homes. Therefore a lowering of mortgage costs would spur the demand for this durable asset, even when the rate of discount increases in the economy. The concern over availability, as distinct from cost, arises because when market interest rates rise, the dominant mortgage lenders are in the worst position to attract and hold funds to lend in the mortgage market, and they normally do not raise their lending rates high enough to equate the amount of mortgage credit demanded with the amount available. As Figure 1 indicates, thrift institutions normally supply most of the funds to finance homes and apartments. They invest predominantly in long-term instruments that are repaid slowly, so that their cash flows from existing loans are relatively smaller than those of commercial banks. Since their portfolios turn over so slowly, it is difficult for them to expand their earnings rapidly when market interest rates jump. They therefore have trouble paying deposit interest rates high

4. See Craig Swan, "The Market for Housing and Housing Services, A Comment," Journal of Money, Credit and Banking, Vol. 5 (November 1973), p. 961. Wisdom is not correct simply because it is conventional, of course, a point that Arcelus and Meltzer stress in their answer to Swan, ibid., and in their original article, "The Markets for Housing and Housing Services," Journal of Money, Credit and Banking, Vol. 5 (February 1973), Pt. 1, pp. 78-99. 


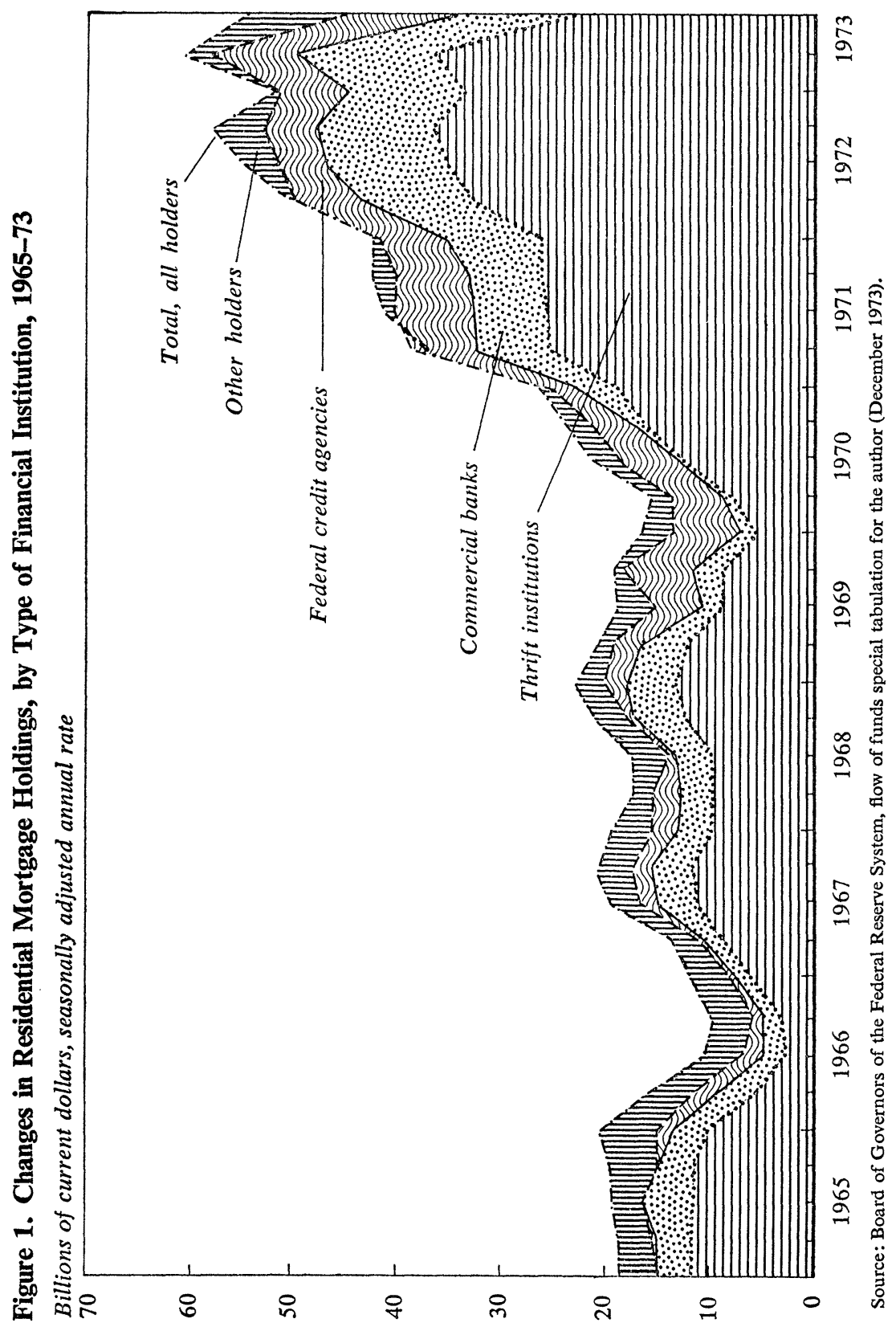


enough to hold deposits or to attract new money, and thus tend to lose funds when market rates rise. Accordingly they tend to restrict their mortgage lending at such times. To a considerable extent they restrict on nonprice grounds, by lending only to depositors or refusing to lend at all, for example. Thus nonprice impediments to availability develop at these institutions.

When the mortgage lending by thrift institutions is squeezed by outflows of funds, commercial banks and other lenders should in principle take their places in the market. In an efficiently functioning market this would be expected to happen, as funds sought their highest return regardless of institutional structure. Unlike thrift institutions, which rely primarily on deposits and Federal Home Loan Bank (FHLB) advances, commercial banks have many instruments for attracting funds on the basis of rate competition, including large certificates of deposit and Eurodollar borrowing. As a result, they can usually obtain funds at some price. ${ }^{5}$ In practice, however, banks do not completely fill the mortgage lending void in the short run, for at least three reasons. First, they do not have the personnel and other facilities to permit expansion of their mortgage lending on the scale required to make up for the drop in the participation of thrift institutions. Second, the real estate lending activities of national banks are still subject to some restrictions under the National Bank Act, relating to maturities, type of security, repayment provisions, and proportions of assets in mortgages. ${ }^{6}$ These have been steadily reduced by administrative rulings of the Comptroller of the Currency, particularly since 1960, but some remain effective. ${ }^{7}$ Third, commercial banks have a good deal of interest to pay on past demand deposits of businesses in the form of lending at times of credit restraint. These past balances, plus formal commitments, make banks large lenders to businesses at such times.

The flows of funds into housing depicted in Figure 1 reflect the operation of these effects on thrift institutions in recent years. Overall mortgage flows slowed when interest rates rose in 1966, 1969-70, and 1973, and mortgage

5. They might also, of course, have to borrow reserves from the Federal Reserve to support this borrowing.

6. 12 U.S.C. 1970 ed., $\$ 371$.

7. Their elimination was recommended by the Hunt Commission and by the President. See The Report of the President's Commission on Financial Structure \& Regulation (1971), pp. 7-18, 77-86, and U.S. Department of the Treasury, Recommendations for Changes in the U.S. Financial System (rev. ed., 1973). 
holdings of thrift institutions tended to slow even more. For instance, total increases in residential mortgages fell from a $\$ 20.48$ billion rate in 1966:1 to $\$ 9.36$ billion in $1966: 4$, but acquisitions by savings and loan associations dropped from a $\$ 7.67$ billion rate to $\$ 0.89$ billion over the same period. Even federal credit agencies reduced their mortgage acquisitions-from $\$ 2.78$ billion to $\$ 1.04$ billion. While the savings and loan associations have maintained their response to interest swings, federal credit agencies have since 1966 moved to fill the lending gap at such times instead of widening it, although they have not fully offset declines elsewhere. Trends in mortgage lending by commercial banks are also noteworthy for two reasons. First, banks have been increasing their residential mortgage lending both absolutely and as a share of all such lending. Banks supplied 16.3 percent of residential mortgage funds in 1965:1 and 15.8 percent in 1971:1. While overall lending more than doubled from 1971:1 to 1973:2, the share of banks increased to 21.6 percent. Second, in recent years banks have shown less tendency to reduce mortgage lending when interest rates rose than have thrift institutions. While acquisitions by savings and loan associations fell $\$ 10.2$ billion from 1973:1 to 1973:3, those by commercial banks actually rose slightly.

It has turned out to be difficult to determine the interest elasticity of housing, even though one would expect it to be clearly high. Table 3 gives several estimates of the interest elasticity of housing starts or residential construction in various econometric models of housing demand. The estimates for the Arcelus and Meltzer, Brady, Swan, and Fair models were derived by the authors themselves. The estimates from the Wharton and Data Resources, Inc. (DRI) models were derived from simulations of exogenous increases in the interest rate variables. No obvious consensus emerges in the table. Taken at face value, the estimates imply widely differing behavior, from highly inelastic (DRI) to rather elastic (Swan, Brady, and Arcelus and Meltzer). Housing finance may have been constrained by availability as well as by costs over the estimation period, possibly in varying proportions. This should be taken into account by estimating the supply elasticity separately, but the three studies that did this-those of Swan, Fair, and Arcelus and Meltzer-came up with very different estimates of the demand elasticity. Because of these distortions, and because credit is so important to housing finance and its cost is such a large element of the undiscounted total cost of a house, one is tempted to agree with the higher range of elasticity estimates. 
Table 3. Estimated Elasticities of Housing to Interest Rates, Six Econometric Models

\begin{tabular}{llll}
\hline \multicolumn{1}{c}{ Model } & $\begin{array}{c}\text { Dependent } \\
\text { variable }\end{array}$ & \multicolumn{1}{c}{$\begin{array}{c}\text { Interest } \\
\text { rate }\end{array}$} & \multicolumn{1}{c}{$\begin{array}{c}\text { Interest } \\
\text { elasticity }\end{array}$} \\
\hline Arcelus and Meltzer & Starts & $\begin{array}{c}\text { Corporate bond } \\
\text { yield }\end{array}$ & $\begin{array}{l}2.05 \text { (supply) } \\
1.75 \text { (demand) } \\
\text { Brady }\end{array}$ \\
Starts & $\begin{array}{c}\text { Conventional } \\
\text { mortgages }\end{array}$ & 2.02 \\
Data Resources, Inc. & Starts & $\begin{array}{c}\text { New corporate } \\
\text { bonds }\end{array}$ & 0.30 \\
Fair & Starts & $\begin{array}{c}\text { New-home FHA } \\
\text { mortgages }\end{array}$ & 0.46 (supply) \\
Swan & Starts & $\begin{array}{c}\text { New-home conven- } \\
\text { tional mortgages }\end{array}$ & 0.32 (demandy) \\
& Expenditures & Corporate bonds & 0.67 \\
\hline
\end{tabular}

Sources: Arcelus and Meltzer-Francisco Arcelus and Allan H. Meltzer, "The Markets for Housing and Housing Services," Journal of Money, Credit and Banking, Vol. 5 (February 1973), Pt. 1, p. 86. BradyEugene A. Brady, "An Econometric Analysis of the U.S. Residential Housing Market," in R. Bruce Ricks (ed.), National Housing Models: Application of Econometric Techniques to Problems of Housing Research, Proceedings of a Conference Sponsored by the Federal Home Loan Bank System (Heath, 1973), pp. 15, 45. DRI-The Data Resources Econometric Forecasting System: A Preliminary Account (Lexington, Massachusetts: Data Resources, Inc., November 1970). Fair-Ray C. Fair, A Short-Run Forecasting Model of the United States Economy (Heath, 1971), pp. 83-87. Swan-Craig Swan, "A Quarterly Model of Housing Starts: A Disequilibrium Approach," Working Paper 39 (Federal Home Loan Bank Board, Office of Economic Research, 1972; processed), pp. 16, 22; Wharton-Ross S. Preston and Lawrence R. Klein, "The Wharton Annual and Industry Forecasting Model: Statement of Equations and Identities" (University of Pennsylvania, Wharton EFA, July 1970; processed).

An empirical estimation of separate availability and mortgage cost effects has been difficult to obtain, but the proliferation of federal mortgage programs to reduce cost and raise availability implies that the federal government has no doubt about the existence of these effects. Although evidence of nonprice disruptions to the mortgage market is not difficult to find, ${ }^{8}$ it is much harder to be sure that the declines in mortgage lending at

8. In the summer of 1973 the conventional wisdom was that California savings and loan associations were making no new mortgage loan commitments. They were still honoring old commitments, however, and these had nearly doubled from early 1972 to mid-1973. (California accounts for about 20 percent of the national mortgage market.) As late as December 8, 1973-well after inflows of funds into savings and loan associations began rebounding nationally - the Chicago Tribune reported, "Some associations are moving back into the market, but others like First Federal Savings \& Loan Association of Chicago-the largest in the state-still will not make a home loan." (Alvin Nagelberg, "Savings and Loan Net Inflows Climb Strongly in November," Chicago Tribune, December 8, 1973.) 
some institutions for nonprice reasons were not made up elsewhere. In a comprehensive review of annual data on the U.S. experience beginning in 1915, Allan Meltzer has concluded that these factors have not had important effects on the housing stock apart from those of general movements in interest rates. ${ }^{9}$ Developments in the mortgage market have materially affected the degree to which the housing stock has been financed with mortgages, with the implication that the credit is taken for many other purposes. Meltzer found that homebuilding is determined by income, interest rates (corporate bond yields were used), the price level, and the price of homes. This implication is also supported by the increases in loans by savings and loan associations for purposes other than buying new homes when market interest rates rise.

If Meltzer's conclusions are correct, the only way to protect homebuilding from restrictive credit conditions is through restrictive fiscal measures to lower rates. Expansionary monetary policy would only delay the impactand only briefly at that. In the discussion that follows, however, it is assumed that developments in the mortgage market have some effect on homebuilding, at least in the short run. Several reasons support this assumption. Most important, Meltzer's results are based on annual data, while the availability effect is asserted to hold during periods of severe credit restraint, which typically last less than a year. Indeed, Meltzer has mentioned the possibility of short-term effects. He discussed this possibility in connection with the effect of Federal Home Loan Bank advances to savings and loan associations on mortgage rates but noted that "it has not been demonstrated that the effect on housing is either large or reliable." 10 In addition, it seems reasonable to believe that for a period of a few months other lenders will not have the facilities and expertise to fill completely the void left by these lenders. In the mobile home market, where demand should be influenced by the same factors affecting housing demand, the financing arrangements are much different. Here, generalized lenders operate on a nationwide basis and mobile home lending and production has fluctuated far less than conventional home lending and building.

Third, using monthly data from June 1959 to November 1969, Fair and Jaffee found that housing starts were positively related to the volume of

9. Allan H. Meltzer, "Housing and Financing," A Study Prepared for the National Association of Home Builders (November 19, 1972; processed), and Arcelus and Meltzer, "Markets for Housing."

10. Meltzer, "Housing and Financing," Chap. 3, p. 39. 
Federal Home Loan Bank advances to savings and loan associations. ${ }^{11}$ Finally, as discussed below, the slowing of residential construction in early 1966 is difficult to explain without reference to savings flows at thrift institutions.

The main discussion here does not depend, however, on the precise route by which restrictive credit conditions depress homebuilding. All that need be assumed is that when a combination of monetary and fiscal policies raises interest rates, homebuilding slows.

The experiences of 1966 and 1969-70 provide a rough indication of the response of homebuilding to restrictive credit conditions. These periods are not particularly helpful by themselves in determining the interest elasticity of demand for housing to the extent that curtailment of cash flows to thrift institutions at the time caused nonprice rationing of funds. Furthermore, income growth slowed, likely curtailing the demand for new homes. But the experience gives some overall idea of the impact of restrictive government policies on housing production. As Figure 2 indicates, residential construction was roughly stable in 1965 and dropped sharply in 1966 . In the fourth quarter of 1965 residential construction in 1958 dollars was at a $\$ 23.8$ billion seasonally adjusted rate. By the fourth quarter of 1966 it was $\$ 18.6$ billion, and the trough of $\$ 18.0$ billion came in the first quarter of 1967 , an overall decline of $\$ 5.8$ billion. By the end of 1967 it had rebounded to early 1966 levels, and it stayed at or above these levels until 1969.

Market interest rates rose throughout most of 1966. The Aaa corporate bond rate was 4.74 percent in January and 5.39 percent in December. The greatest pressure on market interest rates came later in 1966, however. The sharpest run-up occurred in the third quarter, which included the famous "credit crunch" in August. By June 1966 the Aaa corporate rate had risen to 5.07 percent, but in September it peaked at 5.49 percent, then fell to a low of 5.03 percent in February. The Federal Home Loan Bank Board (FHLBB) rate on conventional mortgages on new homes was 5.81 percent in January 1966-only 5 basis points above its 1965 average (which was 2 basis points below the 1964 average). It rose to 6.07 percent in June and 6.49 percent in December 1966.

Inflows of funds into thrift institutions slowed at the same time that construction slowed. From a $\$ 13.8$ billion annual rate in the fourth quarter of

11. Ray C. Fair and Dwight M. Jaffee, "Methods of Estimation for Markets in Disequilibrium," Econometrica, Vol. 40 (May 1972), pp. 497-514. 


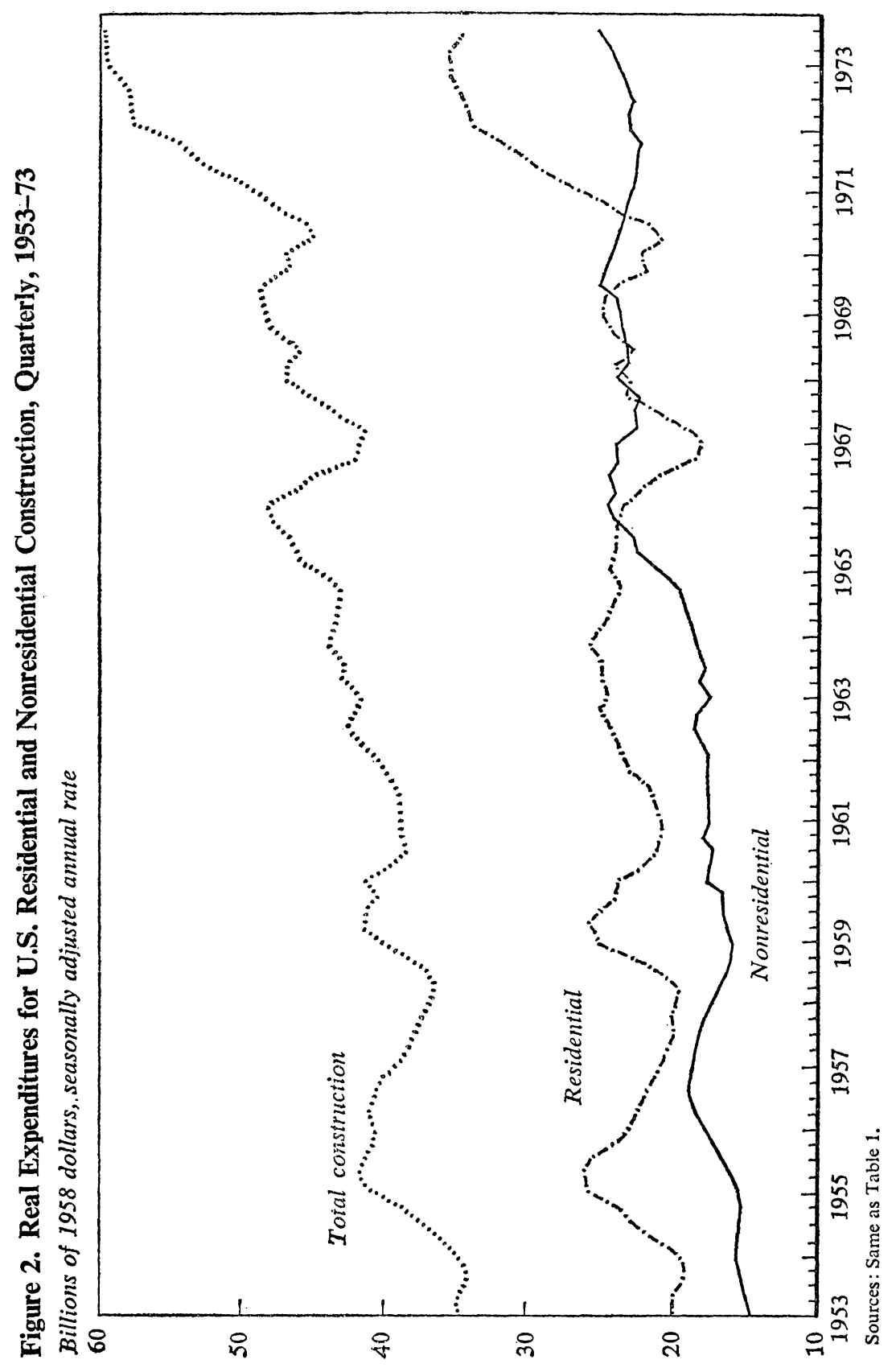


1965 , inflows fell to a $\$ 9.5$ billion rate in $1966: 1$, to $\$ 4.4$ billion in $1966: 2$, and to $\$ 5.1$ billion in 1966:3. By 1967:1 they had surged to $\$ 17.2$ billion.

The weakness in homebuilding early in 1967 can be plausibly related to high interest rates, but the slowing early in 1966 is difficult to explain solely on the basis of an increase in interest rates of about 30 basis points, particularly relative to the sharper increases later. The large impact on construction for these two quarters seems in considerable part due to the slowing of inflows of funds into thrift institutions. Homebuilding apparently was depressed by lessened availability of funds before, and probably during, the time it was falling in response to interest rate increases.

Residential construction in real terms again fell in 1969 and 1970 at and after a shift to a restrictive monetary policy stance. From a peak of $\$ 24.6$ billion (1958 prices) in 1969:2 it fell to $\$ 20.8$ billion in 1970:2, paralleling an upward movement in interest rates:

$\begin{array}{lcc}\text { Date } & \begin{array}{c}\text { Aaa } \\ \text { corporate } \\ \text { bonds }\end{array} & \begin{array}{c}\text { FHLBB } \\ \text { conventional } \\ \text { mortgages }\end{array} \\ \text { November 1968 } & 6.19 & 7.07 \\ \text { June 1969 } & 6.98 & 7.62 \\ \text { December 1969 } & 7.72 & 8.07 \\ \text { May 1970 } & 8.11 & 8.28\end{array}$

Flows of funds into savings institutions showed the same pattern as residential construction. From a $\$ 13.5$ billion seasonally adjusted annual rate in $1969: 1$, inflows fell to $\$ 8.8$ billion the next quarter and to $\$ 4.5$ billion in 1969:4. They inched up to $\$ 5.2$ billion in $1970: 1$, but jumped to $\$ 15.8$ billion and $\$ 21.9$ billion in the following quarters. It is difficult to know what residential construction would have done in the absence of the credit tightness of 1969 and 1970, but after experiencing such a sharp drop in 1966 and 1967, one might guess, it would not have declined. The $\$ 3.8$ billion drop in residential construction thus can be taken as a rough measure of the impact of restrictive economic policies on housing production. It is interesting to note that a larger rise in market rates produced a smaller decline in homebuilding in 1969-70. This may be because part of the 1966 decline would have taken place anyway. It is also true that in 1969 and 1970 thrift institutions were aided by friendlier supervision and more federal programs of mortgage support than in 1966. Mortgage acquisitions by federal credit agencies rose from a $\$ 2.06$ billion rate to a $\$ 6.35$ billion rate, compared with a decline in 1966 (see Figure 1). 


\section{Principles of Efficient Monetary Policy}

The aim of monetary policy actions is to influence aggregate demand, a fact that should not be lost sight of. One-but not the only-route by which this influence becomes effective is the impact of policy operations on market interest rates. In the case of restrictive monetary policy, the aim is to raise real rates of interest in order to encourage deferral of investment in goods whose services are spread over time by raising its costs. Several general principles for efficient resource allocation can be developed.

First of all, efficiency suggests that all real rates on investments of the same maturity should rise together. In this way, future benefits equally distant will be discounted on an equivalent basis. If some real rate were kept artificially low, real resources would be misallocated because the projects to which the rate applied would receive resources that could be more productively employed elsewhere. On this basis the spending that should be deferred longest is that on the most durable goods in the economy, since they give the smallest flow of current services relative to the resources required to produce them.

Second, the length of the production periods of the goods is relevant. The effectiveness and timeliness of monetary policy is enhanced if it impinges on goods that have relatively short production periods, so that the decision to defer production has maximum impact on current resource utilization. For instance, the postponement of construction of a hydroelectric dam that requires five years to build would likely have only small effects on resource utilization during the two or three quarters during which restraint on aggregate demand was desired.

Third, in principle, the resources freed by spending restraint should be those that are mobile and that can be applied easily to enable output to rise in other sectors. This choice would avoid the price rise in those other sectors that otherwise would be the response to increases in aggregate demand. Freeing highly specialized resources that could not or would not be put to use in other sectors would also help reduce aggregate demand, via multiplier effects. But if the freed resources could be employed in producing other goods or services, supply would work to moderate inflationary pressures in those sectors as well. If in most product markets the relation between excess demand and price increases is nonlinear, so that inflation accelerates more than proportionately as excess demand increases in any 
sector, then inflation in the economy is minimized by equalizing excess demand pressures in all markets. ${ }^{12}$ Accordingly, if policy is designed to curb inflation by creating an excess supply of factors of production in a particular industry, this policy will be more helpful the more useful are the factors in excess supply in producing in other industries where excess demand exists. In the case of labor, this result-transferring workers-would also be socially more acceptable than forcing them into unemployment. Although this is an efficiency criterion, it also involves equity for labor and other factors. The owners of highly mobile factors will suffer less than owners of immobile factors because they can move more readily and earn income in other sectors.

This argument also suggests, as a fourth principle of policy strategy, that the demand that is curtailed by monetary policy should not be fully transferred to another sector; that is, if all the spending that was deflected from housing were redirected to some nondurable goods, the only benefit of the restrictive monetary policy would be on the supply side, since aggregate demand would be unchanged.

The fifth principle concerns the issue of the "bang per basis point" effect of monetary policy. To some extent, a restrictive monetary policy works through its effects on values of portfolios. Decision-making units whose net worths are reduced by an increase in market interest rates probably will reduce their spending somewhat. This effect is unlikely to be offset to an important degree by the behavior of the debtors. They typically issue longterm obligations and respond when interest rates decline only by calling debt, if possible, and refinancing at lower rates. These disruptions and wealth transfers are burdensome. Given these balance sheet effects, it would seem to be most efficient and equitable to minimize their incidence on any one portion of the population. This criterion argues for a small but widespread increase in interest rates from monetary policy. It also favors availability effects and nonprice rationing.

Finally, other things being equal, monetary policy should seek to minimize persistent adverse effects on the efficiency of any industry. Over the long run, these industry characteristics are not independent of the stability and growth of the market. For instance, if an industry were continually restrained by restrictive monetary policy because it produced very post-

12. For a discussion of this issue, see Bent Hansen, "Full Employment and Wage Stability," in John T. Dunlop (ed.), The Theory of Wage Determination (Macmillan, 1964), pp. 66-78. 
ponable durable goods, one would expect it to tend to use relatively unspecialized factors of production and perhaps to be less efficient than it might otherwise have been.

\section{Homebuilding and the Efficiency of Monetary Policy}

These principles can be used to evaluate the appropriateness of using housing as the "handmaiden" of monetary policy, and are helpful in identifying the sectors best suited to bear the adjustment burden of monetary policy. With regard to the first principle-that expenditures on especially durable goods should be curtailed more than other types of expenditures when total spending must be restrained-housing units are among the most durable assets in the economy. Housing is an eminently postponable purchase, and any one year's production has a small quantitative effect on the stock. Even in the record production years of the early seventies, housing starts were only about $3 \frac{1}{2}$ percent of the stock of housing units. Postponing the purchase of a house means that people will temporarily not increase the flow of housing services consumed. This marginal loss in one year's consumption pattern (interest rates rarely remain at "crunch" levels for more than a year) is a small fraction of a small fraction of the value of a housing unit. ${ }^{13}$ As an extreme, assume a total cessation of homebuilding for a year. At year-end, the housing stock would be at most $3 \frac{1}{2}$ percent lower than it otherwise would have been. If 10 percent is taken as a generous estimate

13. The other aspect of varying the pace of housing construction is its effect on household formation. With some minor exceptions (such as group quarters and dormitories), a household is defined as an occupied housing unit. If vacancies remained constant and homebuilding slowed, the measured rate of household formation would slow. In practice, this would mean that fewer individuals or couples would leave a large household to take their own housing unit. (It might also slow the pace of separation among married couples.) Little economic analysis seems to have been devoted to the short-run determinants of household formation. Most effort has gone into longer-range projections. Formulations of U.S. housing goals have been in terms of projecting and building for household formations in the ten years ending in 1978, with little attention to the desirability of meeting the goal at a steady rate.

Variations in the rate of undoubling and of forming new households may have important sociological consequences, but the economic aspects are comparable to those of moving from one housing unit to another. An individual who leaves his parents' home and takes his own housing unit is upgrading the flow of housing services (but perhaps not food) he consumes. If he postpones forming a new household, the shortfall in his actual consumption relative to what it would have been in a separate unit is likely to be a similarly small fraction of the value of a housing unit. 
of the ratio of the current housing services to the value of a housing unit, the loss in incremental housing services is 0.0035 of the value of the housing stock.

Second, housing has a very short production period relative to the life of the asset. Single-family homes can be produced in three or four months. As a result, when credit costs increase sharply, the impact quickly appears in homebuilding. Among all very durable assets, housing probably has one of the lowest ratios of production period to expected life. This characteristic materially enhances its attractiveness as an industry that responds to credit conditions.

\section{FACTORS OF HOUSING PRODUCTION}

The third principle concerns the mobility of resources used in housing. It is commonly asserted that housing is a good countercyclical sector because it has a comparatively small amount of specific capital and labor. To the extent that this is true, contractions in homebuilding release resources to other industries to increase capacity and reduce inflationary pressures without generating substantial unemployment.

Labor. Construction labor is sometimes thought to be characterized by such highly skilled workers as carpenters, bricklayers, and steamfitters, who would be unwilling or unable to take up work in other industries when released from construction. On the other hand, some feel that construction laborers are typically unskilled. If this latter view is correct, contraction in homebuilding would release labor capable of being used widely in other industries to expand production and reduce inflationary pressures.

Construction laborers tend to work at one time or another during the year at jobs other than construction. In 1963, 5.4 million workers were employed in contract construction (nonresidential and residential) during the year to fill an average of 3.0 million jobs. ${ }^{14}$ This ratio of 1.8 to 1 compares with a ratio of 1.30 to 1 that year in manufacturing. In 1970, a poor year for homebuilding, the ratio was 1.49 to 1 in contract construction and 1.16 to 1 in manufacturing. ${ }^{15}$ Dunlop and Mills noted that "certain building trades

14. John T. Dunlop and D. Q. Mills, "Manpower in Construction: A Profile of the Industry and Projections to 1975," in The Report of the President's Committee on Urban Housing: Technical Studies (1968), Vol. 2, p. 246.

15. U.S. Bureau of Labor Statistics, Handbook of Labor Statistics, 1972 (1972), pp. 86,89 . 


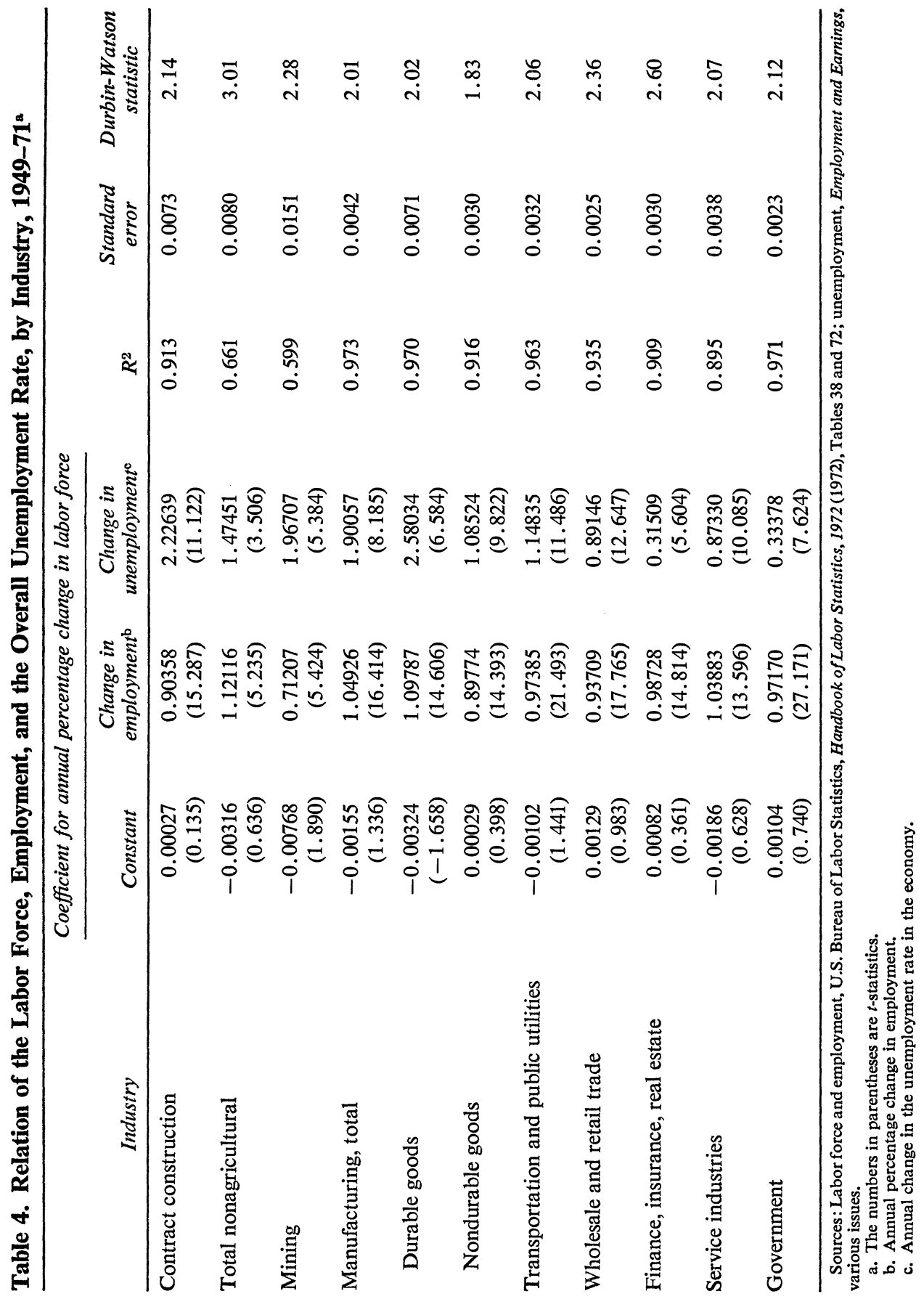


skills (including elements of carpentry and masonry, for example) seem widely distributed throughout the economy, and the construction industry seems able to increase its work force in brief periods at a fairly rapid rate and to a very large degree." ${ }^{16}$ In 1970, 50.9 percent of persons who worked full time during the year and had work experience in construction that year listed construction as the job they held the longest. This percentage is lower than any in manufacturing and transportation, with the exception of apparel at 48.5 percent. $^{17}$

In an earlier issue of Brookings Papers, Craig Swan estimated the relationships among the construction labor force, construction employment, and the overall unemployment rate in the economy. ${ }^{18} \mathrm{He}$ found an increase in construction employment associated with an equal percentage increase in the construction labor force; a change in the overall unemployment rate is associated with a percentage change in the construction labor force over twice as large. On this evidence Swan concluded that changes in construction industry employment had negligible effects on unemployment of construction workers, given the overall unemployment rate in the economy. Presumably, fluctuations in construction employment push workers into (or pull them out of) other industries.

An updated version of Swan's equation appears in the top line of Table 4. With one more year of data, his finding still holds. For comparison, Table 4 also shows estimates of Swan's equation for other industries. They indicate that only in mining is the coefficient of the change in employment very far below unity (0.712); that is, only in mining is a decline in employment not accompanied by an approximately equal decline in the relevant labor force. Thus, only mining appears to have a well-defined labor force not suited to working elsewhere when employment declines, given the state of the overall job market. Construction is therefore not unique in having a labor force with generalized skills. Indeed, among the nonmining industries, the coefficient for construction is the second lowest. The conclusion from these expanded estimations is not that construction is different but that the industrial type of "structural unemployment" is not really a problem for any type of restrictive economic policy-including restrictive monetary policy. Of course, construction workers may experience severe down-

16. "Manpower in Construction," p. 246.

17. Handbook of Labor Statistics, 1972, p. 87.

18. Craig Swan, "Labor and Material Requirements for Housing," Brookings Papers on Economic Activity (2:1971), p. 357. 
grading when they leave construction, and the data do not answer this question. But from a policy viewpoint the fact that they do not remain unemployed is itself significant.

In any case, movement into and out of construction is a common practice for construction labor. Unfortunately, these figures cover all construction and cannot be separated into their residential and nonresidential components. Dunlop and Mills indicate that nonresidential construction tends to be more highly skilled than residential. They note that total construction has twice as many skilled manual workers as laborers and helpers. But they observe that less well-trained workers are more acceptable in residential than in nonresidential building so that residential construction laborers tend to be less skilled than nonresidential workers, particularly when construction labor markets are tight. ${ }^{19}$

A Bureau of Labor Statistics study of the construction of single-family homes showed that 27.9 percent of the on-site hours in building a home were worked by laborers (14.1 percent) and helpers (13.8 percent); 34.9 percent of the total were supplied by carpenters and 34.4 percent by other skilled workers. ${ }^{20}$ This study does not consider the Dunlop and Mills observation that when construction labor markets are tight, more relatively unskilled workers are employed in homebuilding.

Both studies imply that, when homebuilding contracts, a good many skilled workers are released along with the unskilled. While some attempt is probably made to substitute skilled for unskilled workers during periods of falling production in order to maintain a skilled force for future expansions of building, the wage differential between skilled and unskilled workers limits the incentive to make this substitution. One thing that residential construction workers tend to do when housing slows is to go into nonresidential construction. Dunlop and Mills found that nonresidential construction is generally more attractive than residential work to all but "key men," but the cycle in nonresidential building is also different from that of housing, in that it follows GNP more closely. As Figure 2 shows, total construction is more stable than its two components, so that many factors appear to switch between them. The coefficient of variation of total real construction is 0.180 , while that of real residential construction is 0.187 and that of real

19. "Manpower in Construction," pp. 243-45.

20. Robert Ball and Larry Ludwig, "Labor Requirements for Construction of SingleFamily Houses," Monthly Labor Review, Vol. 94 (September 1971), pp. 12-14. The remaining 2.8 percent are professional, supervisory, and office workers. 
nonresidential construction is 0.226 . Fluctuations in residential construction thus tend to be taken up in part by the nonresidential sector, and vice versa. To some degree, then, when the construction industry is not building houses it is building office buildings. Some of the resources released from housing thus tend to reduce inflationary pressures in nonresidential construction.

A movement of factors out of housing and into nonresidential building is also relevant to the well-being of construction workers. Figure 2 shows that the expansion of nonresidential construction has at times been a strong offset to a decline in homebuilding. Homebuilding declines in 1956 and 196566 were accompanied by strong surges in nonresidential construction. The absorption of factors is incomplete, however, for at least two reasons. The first is that, geographically, the contraction of homebuilding would only by coincidence match the expansion in nonresidential construction. Since neither contractors nor workers are perfectly mobile, pockets of unemployment develop even when excess demand exists in the industry. Second, skilled workers tend to be released from homebuilding in proportions different from those required in nonresidential construction. Contractions in homebuilding release heavy proportions of carpenters, bricklayers, and roofers, while nonresidential building requires relatively more operating engineers, plumbers, steamfitters, electricians, sheet metal workers, boilermakers, and ironworkers. ${ }^{21}$ Accordingly, a shift from residential to nonresidential building would likely produce additional unemployment among skilled residential workers and inflation in wages of skilled nonresidential workers.

Moreover, the skilled labor involved in the financing of houses may be less mobile than construction labor, although much less information is available on this component. Competent real estate lending officers, processors, and appraisers are critical to the operations of thrift institutions, and institutions typically do not let them go when interest rates rise. This is partly because in smaller institutions they do other things as well and partly because in all institutions some specific capital is built up in terms of relationships with parties inside and outside the institution. Thus, even if money is otherwise fungible, funds for mortgages can be in short supply when rates rise. For instance, if market rates rise and funds move from thrift institutions to commercial banks (a mild assumption, for they normally go into

21. "Manpower in Construction," pp. 252-53. 
open market instruments), banks would not have staffs adequate to place all the funds in mortgages if they wished to. The same considerations apply to lenders who issue open market obligations bought by thrift institution customers. In the long run they would bid the required people away from the thrift institutions, but squeezes on savings flows of these institutions typically last less than a year. Over such a short period mortgage lending can suffer simply from a shift of funds, separate from any decrease in total credit available to the economy.

Material inputs. Most of the industries that supply homebuilding materials also provide inputs into many other industries and devote only a small portion of their total output to housing. ${ }^{22}$ Except for the three largest supplying industries-lumber and wood products; stone and clay products; and heating, plumbing, and fabricated structural metal products-no industry supplies more than 2.9 percent of the material requirements of residential construction. ${ }^{23}$ These three leading suppliers account for $16.5,15.3$, and 11.7 percent, respectively, of material requirements. On the other hand, homebuilding takes considerably higher proportions of the output of all these industries. ${ }^{24}$ For instance, while paint and allied products make up only 1.0 percent of the material inputs of homebuilding, this activity claims 11.2 percent of the industry's output. Homebuilding takes over 40 percent of the output of the lumber and wood products industry. These comparatively high proportions cast doubt upon the ability of other industries to absorb the resources freed by a decline in homebuilding simply by buying different products from the same suppliers or even from the same industries. The problem is perhaps most acute for lumber, an area stricken by periods of rapid inflation in recent years. Homebuilding uses large quantities of lumber and wood products, but primarily softwood. Softwood timber is not used for much besides homebuilding, so that releasing quantities of this resource does little to ease inflation in other sectors. The furniture industry uses large quantities of lumber, but this is hardwood, a largely noncompeting commodity. Lumber is, however, one of those apparently increasingly rare commodities whose price declines when the quantity demanded falls. Thus, although an easing of homebuilding's demand for

22. See U.S. Office of Business Economics, Input-Output Structure of the U.S. Economy: 1963 (1969), Vols. 1, 2, 3, and Swan, "Labor and Material Requirements for Housing," Table 6, p. 363.

23. Ibid.

24. Ibid. 
lumber would not be likely to reduce inflationary pressures in other sectors, when housing production falls lumber prices should fall, reducing the upward pressure on home prices.

\section{MINIMIZING PORTFOLIO DISRUPTIONS}

The fourth principle for efficiency in using monetary policy-minimizing the portfolio disruptions of interest rate changes-implies that housing should be sheltered little, if at all, from monetary policy. Minimizing these impacts and spreading the effects of rate changes generally around the economy argues that housing should be permitted an unimpeded response to increases in market interest rates. To protect housing would be to force market interest rates to rise more than they otherwise would have so as to extract from other sectors the contraction that housing would have contributed. This pattern worsens the disruption to balance sheets in the economy and the redistribution of wealth from interest rate changes. To the extent that the aim is to keep these to a minimum, housing should be permitted to respond to restrictive credit market conditions so that interest rate swings are as modest as possible. In fact, this argument implies that restrictions on availability and nonprice rationing are helpful.

\section{THE EFFECT ON LONG-RUN EFFICIENCY}

Finally, it is desirable to use monetary policy in such a way as to minimize disruptions to the long-run efficiency of any industry. In the case of housing, the gains in efficiency in construction might well outweigh the losses in efficiency in other sectors if housing production were made more stable and production in other sectors fluctuated more. Alternatively, perhaps other sectors could be made less cyclical so that housing could be more stable and therefore more efficient. This second possibility is, of course, attractive, but the verdict obviously depends upon the costs of effecting it.

Without in fact stabilizing housing activity it is impossible to test directly the hypothesis that if housing production were more stable the industry would be more efficient. Evidence purportedly showing that the efficiency of the housing industry has not improved over time has been used to support the hypothesis that the fluctuations in production have retarded the improvement in efficiency. This evidence is based primarily on pre- 
1950 experience and finds efficiency growth in construction to be considerably slower than that in the remainder of the economy. ${ }^{25}$ These early studies have recently come under closer scrutiny by Gordon and by Sims. ${ }^{26}$ Gordon reexamined and challenged the view of the earlier studies that construction prices paralleled input cost indexes. The only firm evidence he found for this important underlying assumption was the comparison made by Grebler, Blank, and Winnick of a housing input cost index with a housing output cost index. This comparison applied to only one construction component and ended in 1934.

Sims reexamined the whole efficiency question and tried a different approach to detecting changes. He separated improvement in efficiency into components arising on the one hand from applying new technology and on the other from varying quantities of inputs in response to variations in their relative prices. While attention had previously been focused on identifying the first sort of change, Sims found evidence of the second kind for the period after the Second World War. He also found that construction was technically stagnant in the 1929-47 period, as the studies done in the 1950s had concluded. Thus homebuilding has been getting more efficient since 1947 in the sense of varying the combinations of inputs in response to variations in relative prices, if not in the sense of developing new technology.

One implication of fluctuations in housing production is that firms should gear their production processes to the likely degree of stability of output. A well-established part of price theory holds that a firm expecting high variability in the scale of its production should adopt production techniques that yield relatively constant unit costs over a wide range of output rather than picking a process that, at some narrower range of production levels, yields the lowest attainable unit cost. Housing might well combine factors in optimal proportions, given the production processes used, but be capable of combining them to produce at a lower cost over a narrower range with another production function. A study of cost functions in residential construction would be interesting and ought to reveal relatively flat portions

25. See, for example, Miles L. Colean and Robinson Newcomb, Stabilizing Construction: The Record and Potential (McGraw-Hill, 1952); and Leo Grebler, David M. Blank, and Louis Winnick, Capital Formation in Residential Real Estate (Princeton University Press for the National Bureau of Economic Research, 1956).

26. Robert J. Gordon, "A New View of Real Investment in Structures, 1919-1966," Review of Economics and Statistics, Vol. 50 (November 1968), pp. 417-28; Christopher A. Sims, "Efficiency in the Construction Industry," in The Report of the President's Committee on Urban Housing: Technical Studies, Vol. 2, pp. 145-76. 
over considerable ranges of output. Some changes in the production process, particularly in off-site production of components, would almost certainly accelerate if homebuilding became more stable, with the likely result of decreasing costs. It is, however, difficult to point to a clearly superior production process in use elsewhere that housing cycles have discouraged in the United States, perhaps because other industrialized nations have experienced housing cycles as bad as, or worse than, those in the United States.

\section{ENTREPRENEURIAL SERVICES IN HOMEBUILDING}

One part of the consequences of fluctuations in homebuilding on the long-run efficiency of the industry that is subject to quantification is their impact upon the supply of capital to the industry. In particular, the greater the variation in the pace of homebuilding, the more reluctant should entrepreneurs be to enter the industry. Thus the supply price of capital to the industry should be raised by increases in the variability of production.

Homebuilders are typically highly leveraged firms that are low on capital and vulnerable to swings in interest rates and in the level of housing construction. The sharper are the contractions in homebuilding-or, to the extent that homebuilders make the switch to nonresidential building, in the sum of the two-the more homebuilders leave the industry; the more hesitant they are to return; and the more likely they are to adopt production processes that minimize cost per unit over a larger range of production volumes, rather than choosing the process with the lowest minimum cost per unit of output. Variations in the volume of homebuilding should therefore affect the supply price of capital and entrepreneurial services to homebuilding. ${ }^{27}$ The higher the volatility of housing construction, the higher the rate of return on capital in homebuilding that should be demanded. A similar pattern should appear in other industries as well, but it might be more pronounced in housing because variability is alleged to be more pronounced there.

The first part of the argument that high volatility raises the required rate of return in housing is that homebuilding activity experiences more fluctuation than other industries do. Table 5 tends to support this assertion. It re-

27. For an indication that this point was feared by the Federal Reserve in 1966, see Sherman J. Maisel, Managing the Dollar (W. W. Norton, 1973), pp. 99-100. 
Table 5. Coefficients of Variation around Logarithmic Trends of Major Spending Components of Gross National Product, Constant and Current Dollars

\begin{tabular}{lcc}
\hline & \multicolumn{2}{c}{ Coefficient of variation } \\
\cline { 2 - 3 } \multicolumn{1}{c}{ Spending component } & $\begin{array}{c}\text { 1958 dollars } \\
(1947: 1-1973: 2)^{\mathrm{a}}\end{array}$ & $\begin{array}{c}\text { Current dollars } \\
(1946: 1-1973: 2)^{\mathrm{a}}\end{array}$ \\
\hline Investment in residential structures & 0.0417 & 0.0598 \\
Durable goods consumption & 0.0233 & 0.0259 \\
Nondurable goods consumption & 0.0037 & 0.0093 \\
Services consumption & 0.0027 & 0.0052 \\
Investment in nonresidential structures & 0.0249 & 0.0298 \\
Producers' durable equipment & 0.0358 & 0.0347 \\
Government purchases & 0.0317 & 0.0337 \\
\hline
\end{tabular}

Sources: Derived using data from the sources cited in Table 1. a. Period of fit.

ports coefficients of variation around logarithmic trend lines of major GNP spending components. They demonstrate that investment in residential structures is the most variable of these components in both current and constant dollars. Nonresidential construction, both nominal and real, displays much less variability, less in fact than investment in producers' durables.

Since the fluctuations in activity are indeed greater in housing, it should be possible to detect this influence on the rate of return on capital required in the industry. Homebuilding firms are typically rather small, building only a few houses a year under the direct supervision of the owner of the firm. Data on such firms would be available only through their tax returns, which the Internal Revenue Service does not release. However, the publicly owned homebuilders, for which data are available, tend to be the larger firms in the industry, and although many are diversified into other fields (Levitt and Sons is owned by ITT, for instance), many specialize in singlefamily homebuilding. While their experience in many ways may not exactly parallel that of small builders, the forces should work in the same direction; that is, a market development that proves unfavorable to a large builder might well drive many smaller ones out of business.

Variations in the required rate of return in homebuilding ought to approximate variations in the earnings-price ratio, or its inverse, that the market gives to homebuilding stocks. This ratio should vary with developments in housing markets. Unfortunately, there are no established indexes 
of homebuilder stocks whose price-earnings ratios could be calculated. ${ }^{28}$ Accordingly, a new index was calculated, based on information on homebuilders listed on stock exchanges and traded over the counter. ${ }^{29}$ Priceearnings ratios of these largest single-family builders were then weighted by their 1972 volume of single-family homes built ${ }^{30}$ to form an average ratio for the industry. It is calculated as of the end of the quarter (to make it comparable with Standard and Poor's overall index of price-earnings ratios for 500 stocks). Since housing stocks have only recently become widely held and traded, the index begins with 1969:1.

The first thing to be noted about this price-earnings (PE) ratio is that in the post-1968 period over which it is available, it is higher than the average $\mathrm{PE}$ ratio of Standard and Poor's 500-stock index. The average PE ratio for housing was 24.94 , while that of the broader index was 16.91 , so that the rate of return in housing was lower. Overall, then, fluctuations in housing have not offset other favorable effects on this PE ratio. The favorable effects seem to include an optimistic outlook for growth in housing over this period. This favorable outlook likely reflects in no small measure the substantial efforts the federal government has made to ensure that every American has a safe and decent housing unit. These efforts have been directed at meeting the goal primarily by building new houses for those without them, so that the programs have improved the growth prospects for the homebuilding industry.

Second, the housing PE ratio is high relative to the Standard and Poor's probably because housing follows a different cycle from most other sectors. Lintner has shown that the PE ratio of a stock depends not only on its variance but also on its covariance with general economic activity or general

28. Standard and Poor's Corporation has a classification called "real estate," but the six stocks in this group include only one homebuilder (Kaufman and Broad). The rest are suppliers of credit and building materials.

29. The companies are U.S. Home Corporation, Kaufman and Broad, Centex Corporation, Ryan Homes, Inc., The Larwin Group, Inc., Hallcraft Homes, Inc., Del E. Webb Corporation, the Presley Companies, Shapell Industries, Inc., and Lennar Corporation. The ninth largest single-family homebuilder, Weyerhaeuser, was excluded because it does too much of its business outside the industry. Del Webb was included on the assumption that it is viewed more widely as a housing stock and because it has been listed for a long time. Some spot checks indicated that the results would be little affected by its exclusion. The index is weighted by the volume of single-family home sales, not total revenues.

30. These sales figures were obtained from Professional Builder, Vol. 38 (July 1973), pp. $159,161$. 
trends in common stocks. ${ }^{31}$ Stocks with low covariances with the general indexes provide a diversification against the risk that the values of all stocks in a portfolio will fall together as the market falls. Since housing tends to move in a cycle different from that for the rest of the economy, prices of homebuilding stocks should have lower covariances with the general level of stock prices than prices of most other stocks. This value for diversification purposes should therefore enhance the PE ratios of housing stocks.

Price-earnings ratios of stocks should reflect not only the prospect for growth in earnings but also the market's valuation of the expected fluctuation of the output and earnings of the firm or industry. To the extent that the actual course of output and earnings corresponds to the market's expectation, the price-earnings ratio will have been justified, and one should be unable to observe a relationship between the $\mathrm{PE}$ ratio and the output or earnings of a firm or industry. Only if present results surprise the market or if future growth prospects are revised will PE ratios and activity be related. If unanticipated fluctuations in residential construction occur, they should have an impact on $\mathrm{PE}$ ratios for housing. Intuitively, one would expect that a higher level of housing construction than anticipated would raise the PE ratio for housing and a lower one would reduce it. On the other hand, proponents of stabilizing housing maintain that very large swings in construction tend to depress the $\mathrm{PE}$ ratio because they add risk to the industry. To check for the effects of levels and extreme variations in output, the following equation was estimated:

$$
P E H / P E S P=a_{0}+a_{1} H+a_{2} H^{2}+a_{3} G N P+a_{4} R G 35+a_{5} T,
$$

where

$P E H=$ an index of the price-earnings ratio of homebuilding stocks

$P E S P=$ the price-earnings ratio of Standard and Poor's 500-stock index

$H=$ a measure of real housing activity

$G N P=$ gross national product in 1958 dollars

$R G 35=$ the yield on three- to five-year Treasury securities

$T=$ a time trend.

The volatility argument says that unexpected changes in residential construction should produce $a_{1}>0$ and $a_{2}<0$. If housing is more strongly

31. John Lintner, "Security Prices, Risk, and Maximal Gains from Diversification," Journal of Finance, Vol. 20 (December 1965), pp. 587-615. 
influenced by GNP changes than the industries covered by the S\&P index are, $a_{3}$ should be greater than zero, and vice versa. Assuming that housing and the S\&P industries respond negatively to interest rate increases, if housing responds less, $a_{4}$ should be greater than zero and vice versa. The trend variable is included to help account for the influence of strong upward trends in these variables.

If there is a negative nonlinear relationship between housing and the dependent variable such that $a_{2}<0$, the implication is that issuing stock is a more costly way to finance operations if output varies than if output is constant, because the average of price-earnings ratios for two levels of production will be lower than the price-earnings ratio of the average level of output. Deviations on either side would average out for a simple linear relationship, but not for a negative nonlinear relationship.

The estimation of this equation using gross private domestic fixed investment in residential structures (ICR) as the measure of housing activity is as follows (the numbers in parentheses are $t$-statistics):

$$
\begin{aligned}
& \text { PEH } / \text { PESP }=0.964+0.620 I C R-0.00991(I C R)^{2} \\
&(0.254)(4.027)(3.475) \\
&-0.0160 G N P+0.179 R G 35+0.0213 T . \\
&(4.692) \quad(2.742) \quad(1.351) \\
& R^{2}=0.911 ; \text { standard error }=0.1208 ; \text { Durbin-Watson statistic }=2.604 .
\end{aligned}
$$

It reveals a significant positive relationship between the dependent variable and the level of housing activity and a significant negative one for the squared term. Apparently, over the 1969-73 period fluctuations in output were greater than anticipated by the market. The GNP influence is significantly negative and that of interest rates significantly positive.

To see the effect on rates of return, consider a 25 percent decline in real residential construction in one quarter brought about to cool off the economy. The mean of real residential construction during the period was 28.58 billion 1958 dollars. With mean values, this lowers PEH/PESP by 4.936 . Of this, 4.430 comes from the $I C R$ and 0.506 from the squared term. Assuming that the $S \& P$ ratio is unaffected, the squared term lowers the priceearnings ratio in housing to 16.385 , raising the earnings-price ratio from 0.0401 to 0.0610 . The implication of this negative squared term is therefore that the average required earnings-price ratio is higher the more variable the output, because the average of price-earnings ratios at various output levels is below the ratio at the average output level. 


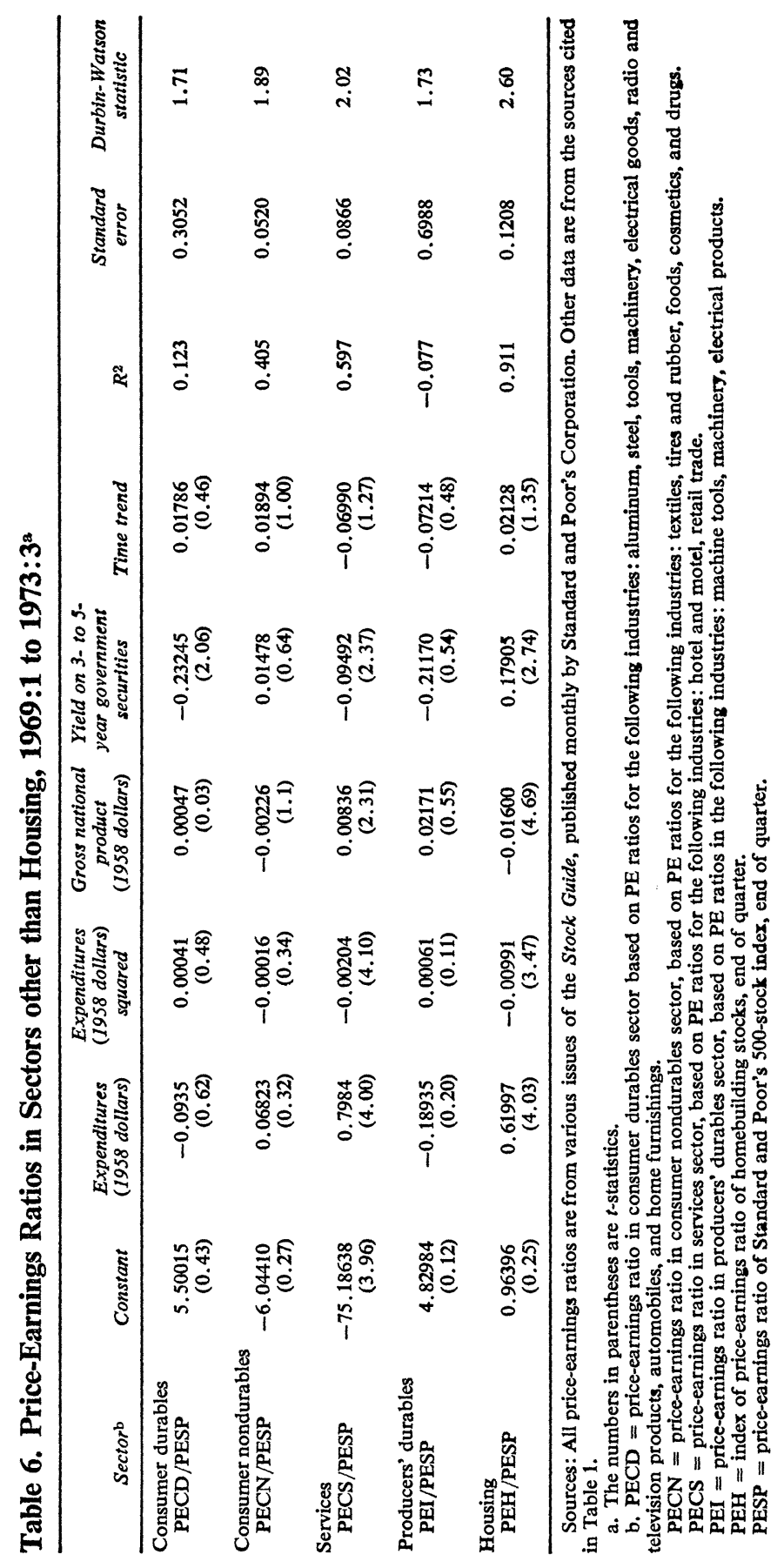


Apart from the degree of the impact, this type of effect might not be confined to housing. Any industry ought to respond positively to unexpected increases in its output and negatively to unexpected fluctuations in its level of production. Table 6 extends the analysis to other GNP components by combining price-earnings ratios from component industries. The priceearnings ratios of representative component industries were weighted according to the proportions of Federal Reserve indexes of industrial production. With the exception of the interest coefficient for consumer durables, the only sector with significant coefficient estimates was services. Here the level variable had a positive influence and the squared term a negative influence, as in housing. But the signs of the GNP and interest rate variables were the opposite of those for housing, apparently reflecting once again the difference from other sectors in the relationship between housing and GNP over the cycle. Except for services, then, no evidence emerges that levels of output and their variability were unanticipated by the market over this period.

The coefficient of the level term is larger for services than for residential construction, but that for the squared term is smaller for services. Therefore a $\$ 100$ swing in output has a larger negative impact on the PE ratio through the squared term for housing than for services. Since the services sector is much larger than residential construction, an equal percentage decline in production of services would hit the $\mathrm{PE}$ ratio harder, but a 25 percent decline in services over a quarter is admittedly highly unlikely. Assuming the same dollar decline in real services, $\$ 7.145$ billion (25 percent of mean residential construction), and considering only the impact of the squared term, the earnings-price ratio for services rises from 0.0430 to 0.0465 .

Thus, it appears true that large swings in housing production can have relatively large effects on the supply price of capital in homebuilding. Given dollar swings have larger depressing effects on housing than on the other sectors reported in Table 6. Because these sectors are considerably larger than housing, this is not especially surprising. If high interest rates hit a small subsector of services, the dollar impact through its squared term might be far greater. Indeed, this is an essential part of the housing story: the economy as a whole receives stabilizing help on a fairly large scale from an industry that accounts for only about 4 percent of GNP. The handmaiden industry ${ }_{\mathrm{E}}$ is relatively small and frail, and the estimates show that these fluctuations take their toll on it. 
The discussion has demonstrated that in many ways homebuilding is well suited to bearing a large share of the burden of stabilization policy. The durability of its product, the short production period, and its relatively mobile resources, together with the advantages of minimizing portfolio disruptions from interest rate changes, argue for laying a heavy part of the load on housing. On the other hand, the hardship such a policy imposes on the industry also appears to be very real. It is difficult to know how much more efficient homebuilding would be or what technological breakthroughs could be achieved if housing production were more stable, but it is easy to imagine that some improvements would take place. Sharp fluctuations in output also discourage capital from entering the industry in a measurable way. A given dollar swing raises the supply price of capital in housing more than in any other major category of GNP. The impact is five times as great on housing as on services, the only other sector where such an impact was estimated. Large builders feel the effects through housing stock prices. For the small builders who dominate the industry, the effects are likely to be even more severe. For many of them, the counterpart of a sharp rise in the earnings-price ratio of large firms will be bankruptcy. And rather than demanding a higher return on capital in the future, they might simply never again consider entering the industry.

\section{Policy Implications}

The decision about protecting housing from restrictive credit market conditions is thus not an easy one. In making a decision to do so the cost and benefits of particular means are important. Three general approaches to insulating housing production from restrictive conditions in the credit market can be distinguished: (1) cushion homebuilding by compromising the aggregate objectives of economic policy, in particular sacrificing price stability; (2) increase the flexibility and short-run use of fiscal policy to lessen the need for interest rate swings; and (3) shift the burden of tight money away from housing by increasing its impact on other types of creditsensitive expenditures while achieving the same degree of restraint on overall spending in the economy.

\section{PROTECTING HOUSING WITH MONETARY POLICY}

In the past when interest rates have risen and concern has developed over housing, monetary policy has been one method used in the attempt to pro- 
tect it. This has been a popular way of shielding housing over the business cycle in the United States, although its use is usually deplored by the people who employ it, the Federal Reserve. Federal Reserve policy has not uncommonly been less restrictive than it would otherwise have been out of fear of restraining housing construction unduly. For instance, in the published record of the July 18, 1967, meeting, of the Federal Open Market Committee, one reason cited for not moving to a more restrained policy was "that any significant further increases in market interest rates might reduce the flows of funds into mortgages and slow the recovery under way in residential construction activity." 32

It can be argued that this type of cushioning elevates housing to a height of national priority for which there is no legislative basis. While the legislation setting forth U.S. housing goals calls for improvement in the national housing stock, it does not require that it take place at a constant rate over the business cycle. Furthermore, the Employment Act of 1946 calls upon the government to promote maximum employment and purchasing power, and purchasing power is eroded by the inflation that follows from an excessively expansionary monetary policy.

At best this type of rate protection is temporary, for the increases in money that initially offset the upward pressure on rates will in time generate increases in income and price expectations that will send rates up to at least the levels they would have reached anyway. ${ }^{33}$ Such a policy affords rate protection to all borrowers, not just those in the housing market. Housing gets no greater a share of funds than it would when rates are at "normal" levels, and any nonprice impediments reduce the share of funds to housing as soon as rates rise. General monetary policy operates primarily directly on the interest rate on borrowing for housing, rather than on availability.

Protection with monetary policy has severe implications for inflation. If it is protecting, the Federal Reserve is, by definition, following a less restrictive policy than it feels is warranted to meet overall economic goals. Thus this policy is more inflationary than otherwise, for it stimulates all borrowers, not homebuyers selectively, to borrow and spend more than ap-

32. Federal Reserve Bulletin, Vol. 53 (November 1967), p. 1899.

33. William E. Gibson, "Interest Rates and Monetary Policy," Journal of Political Economy, Vol. 78 (May/June 1970), pp. 431- $\rightarrow$ Phillip Cagan and Arthur Gandolfi, "The Lag in Monetary Policy as Implied by the Time Pattern of Monetary Effects on Interest Rates," in American Economic Association, Papers and Proceedings of the Eightyfirst Annual Meeting, 1968 (American Economic Review, Vol. 59, May 1969), pp. 277-84. 
propriate for acceptable price performance. The inflationary potential could be offset by an appropriate change in taxes or government spending, or both, but as a practical matter these changes are unlikely to be feasible, as discussed below.

On the other hand, it can be argued that price stability is not sacrosanct and that if the consequences of an appropriate monetary policy for homebuilding are deemed to be too severe, this goal should be sacrificed in order to protect housing. ${ }^{34}$ How severe those consequences for housing would be and what alternatives are available are crucial in determining whether to follow such a policy. It has been followed at times in the past and could conceivably be attractive in the future, but as is mentioned below, some superior tools are now available which could be used first.

\section{FISCAL POLICY}

More frequent and flexible use of fiscal tools has long been advocated as an aid to housing, particularly by the executors of monetary policy. ${ }^{35}$ The proposals typically include increasing the use of automatic or discretionary stabilizers, such as a variable investment tax credit or a variable income tax surcharge. These proposals seem unlikely to be enacted in the near future, if ever, as they involve relinquishing some legislative control over spending and taxes. Discretionary changes in taxes and spending have proved difficult to obtain from Congress in time to be effective, and spending delays not directed by Congress face court challenges. The administration has considerable latitude from year to year in directing the fiscal thrust of the budget, and appropriate flexibility here can help stabilize interest rates. As more and more increases in outlays become built in, this flexibility is reduced, however. Furthermore, it is not easy to redirect budget policy in midyear, should conditions call for it.

\section{SHIFTING THE ADJUSTMENT BURDEN}

The third approach to supporting homebuilding is to attempt to shift the burden of restrictive credit conditions away from those on whom it would

34. This point was made by Arthur M. Okun in "Rules and Roles for Fiscal and Monetary Policy," in James J. Diamond (ed.), Issues in Fiscal and Monetary Policy: The Eclectic Economist Views the Controversy (DePaul University, 1971), pp. 51-74.

35. See "Ways to Moderate Fluctuations in the Construction of Housing" (official policy statement of the Board of Governors of the Federal Reserve System), Federal Re- 
otherwise fall. This means is increasingly relied on, and a wide variety of federal credit programs in the United States seek to implement it. Included are such programs as purchases of mortgages by the Federal National Mortgage Association (FNMA) and the Federal Home Loan Mortgage Corporation; FHLB advances to savings and loan associations; guarantees of mortgage-backed securities by the Government National Mortgage Association (GNMA) and its "tandem plan" purchases, which absorb part of the discounts on insured mortgages.

These programs have three common elements. First, they loosen the availability constraint by providing funds at some price to mortgage borrowers who otherwise could not obtain them at any price from traditional lending sources. Second, they subsidize housing. Some do so to only a modest extent, but all do so in some way. Third, they are designed to transfer the stabilization burden to other sectors through the upward pressure on the general level of interest rates exerted by issuing debt to finance these programs.

Perhaps their main goal is to maintain an availability of funds over the short run when traditional mortgage lenders experience reduced inflows of deposits. Some programs supply funds to thrift institutions and some to the mortgage market directly. Both ways usually involve costs to borrowers that rise as market rates rise. They mean, however, that the thrift institutions need not find themselves entirely without funds to honor commitments or, even worse, insolvent. They also tend to ensure that homebuyers can find financing at some price, even if it is very high by historical standards.

This function increases the efficiency of allocation of financial resources because without it funds tend to be allocated on such nonprice grounds as length of customer relationship and location of borrower. When thrift institutions have depleted their lendable funds, some borrowers receive loans at rates that, in many cases at least, do not rise by as much as market rates, while others who are willing to pay higher rates are unable to secure a mortgage loan at any price. Federal credit programs allow these unsatisfied borrowers to bid for funds on the basis of price, which they could not do before. At very high mortgage rates many potential borrowers will delay buying homes until rates decline, but efficiency is raised thereby since the

serve Bulletin, Vol. 58 (March 1972), pp. 215-25; and Financing the Nation's Housing Needs, A Statement on National Policy by the Research and Policy Committee of the Committee for Economic Development (CED, 1973). 
funds tend to go to borrowers willing to pay the high rates. In addition, these programs facilitate the geographic mobility of mortgage funds. Increasing the liquidity of mortgages and reducing availability constraints thus improves the allocation of financial resources both among regions and among borrowers. At the same time, however, it means that a given change in market interest rates has a smaller impact on spending than it otherwise would.

The subsidy element in these programs, though always present, is in many cases difficult to quantify. There are two types of subsidy, one very obvious and the other less so. The first includes outright cash payments and loans or guarantees at interest rates far below the market. Most such programs are not designed to provide more subsidy when interest rates rise but rather are concerned with general assistance to housing. But there are two exceptions. The first is the GNMA mortgage purchase program, the so-called tandem plan. When discounts on FHA- and VA-insured mortgages rise above a threshold level (four points for new homes and five for existing), GNMA stands ready to buy such mortgages at prices reflecting these threshold discounts (96 and 95). It then resells the mortgages at market prices and absorbs the difference, which is an outlay in the federal budget. ${ }^{36}$ Second, some programs of the Department of Housing and Urban Development provide for loans at 1 percent interest to qualified borrowers, so that the value of this benefit (and its cost) rises with market rates.

Programs with smaller and less straightforward subsidy elements generally subsidize by not charging for the full value of the agency status of the issuer of the security or of the federal guarantee (either on a loan to a borrower or on a security issued by the agency used to raise funds to buy mortgages). One example is the program of Federal Home Loan Bank advances, which embodies two kinds of subsidy. First, interest rates on advances to savings and loan associations are set by the regional Home Loan Banks based on each institution's average cost of funds. One source of the banks' funds is deposits of member associations, on which a return below the market rate is paid. This low-cost source of funds is included in the averaging, so that rates on advances are below the banks' costs of borrowing in the open market. ${ }^{37}$ The heaviest lending of these banks usually takes place

36. In practice, the mortgage originator usually buys the mortgage back and simply receives a check from GNMA for the difference.

37. This pricing procedure is not without some justice since associations are in part borrowing back their own funds, but it does mean that they do not face the true marginal cost of the funds. 
when marginal costs of funds are well above average costs. Second, the banks enjoy agency status, which some interpret to mean that while the securities they issue are not legal obligations of the U.S. government, the government would in practice make good any default. Even without this presumption, however, agency status has value. It makes the obligations eligible for purchase by government trust funds and elevates their acceptability for purchase by government-supervised institutions such as national banks and federal savings and loan associations. Pricing advances on the basis of cost of funds thus gives associations the value of this status as well.

Since these programs do not directly augment the pool of savings, the issuance of agency securities to finance them pushes up market interest rates elsewhere in the economy. This aspect should assist monetary policy, because to the extent that housing is not restrained other spending should be, thus distributing the burden of monetary policy around the economy. Comparatively little is known about precisely which spending flows are hit by switching restraint from the housing sector. One close observer of financial markets has suggested that those denied credit when federal agencies preempt funds (for any purpose) are "some state and local governments, medium-sized and smaller businesses, some private mortgage borrowers not under the Federalized umbrella, and some consumer sectors." 38

The definitive answer to this question requires a large-scale econometric model of the economy and the financial system, since it is a general equilibrium problem. Most such models, however, are not well equipped to answer it because of their limited structures of interest rate determination. In the FRB-MIT-Penn model, for instance, short-term interest rates are determined by the demand function for money, and long rates are constructed from short rates with term structure coefficients. Such a model will show an effect of federal programs on interest rates if GNP is affected, but it is not designed to distinguish which rates rise and which fall.

One model designed to answer such questions is the flow of funds model developed by Bosworth and Duesenberry. This semi-annual model has a richer range of determinants of various interest rates and, as a result, is helpful for the purpose at hand. In two papers based on this model, Bosworth and Duesenberry simulated the effects, first, of a $\$ 1$ billion increase in FNMA mortgage holdings and then of holding FNMA purchases in

38. Henry Kaufman, "Discussion," in Housing and Monetary Policy, p. 104. Kaufman also discusses in some detail the dangers of federalizing credit markets by the spread of federal credit programs to more and more sectors and industries. 
1969-70 to their 1966 levels. ${ }^{39}$ In these simulations FNMA purchases had sharp temporary positive impacts on GNP because other spending was not immediately depressed by the same amount. ${ }^{40}$ In the 1969-70 simulation, holding FNMA purchases to 1966 levels results in a level of FNMA holdings $\$ 4.7$ billion below the actual path in the second half-year and a $\$ 6.0$ billion deduction in GNP. After two and a half years of this policy, FNMA holdings are $\$ 10.1$ billion lower than the actual, but the GNP impact has vanished, as the offsetting response in other spending has appeared. At that point the Baa corporate bond rate would be lower by 37 basis points, the state and local borrowing rate by 34 points, the three- to five-year Treasury bond rate by 48 points, and the three-month bill rate by 43 points. The bulk of the offset in overall spending comes from business investment spending and state and local government spending, but it is long delayed compared with the response of residential construction. The authors analyze the slowness of offsetting forces accompanying the quick response of residential construction to changes in mortgage lending:

We find that there is a significant offset to the stabilization impact of FNMA mortgage purchases, but these effects are delayed considerably in time behind the initial change in residential construction. Much of this response lag is concentrated in the financial sector. Long-term rates relevant for business investment respond only slowly to changing short-term rates because of expectational lags. Deposit holders do not immediately realign their portfolios in response to changing levels of market rates relative to deposit rates. Mortgage lending institutions take several periods to adjust the composition of their assets between mortgages and direct market securities. In the real sector business investment responds very slowly to changes in the cost of borrowing funds..$^{41}$

Thus, rates on business investment expenditures and on state and local government bonds rise in the wake of agency financing, but since they are slow to respond, aggregate demand increases in the interim.

The Bosworth-Duesenberry simulations yield a result that, if correct, has very important implications for the issue of protecting homebuilding. Homebuilding may be the only component whose impact on demand can be invoked rapidly enough to help. If this is true, then federal credit pro-

39. Barry Bosworth and James Duesenberry, "A Flow of Funds Model and Its Implications," in Federal Reserve Bank of Boston, Proceedings of the Monetary Conference, 1973 (FRBB, 1973); and "Policy Implications of a Flow of Funds Model," forthcoming in the May 1974 proceedings issue of the Journal of Finance.

40. This positive impact also appears in the FRB-MIT-Penn model.

41. Bosworth and Duesenberry, "Policy Implications." 
grams simply mean that market interest rates must be pushed even higher because one way or another homebuilding must be restrained. In this case, these programs help allocate mortgage funds efficiently, but they require higher interest rates than otherwise to stabilize the economy.

\section{OUTCOME}

The protection question comes down to a financial side and a real side. On the financial side, allocating funds on nonprice grounds has no special advantage. In other words, unless some consideration about real activity makes it imperative not to do so, programs should be established to allocate whatever funds are available for mortgages on the basis of interest rates rather than nonprice considerations. Hence, a government program for assembling mortgage funds and allocating them on the basis of rate competition would be desirable at times when rising market rates cut off the funds of traditional mortgage lenders. In practice, no such entirely unsubsidized government program exists. However, it would also be desirable to offset the institutional restraints on mortgage funds during periods of high rates, which arise from added bank lending to businesses that have held demand deposits and the reluctance of lenders to raise mortgage rates as fast as market rates rise. On the other hand, the evidence that residential construction responds more quickly to changes in credit conditions than do other types of spending implies that federal credit programs supporting the mortgage market tend to be inflationary for a given path of monetary growth. In addition, this price pressure comes at precisely the time when policy is concerned with dampening demand and inflation.

To a considerable extent the evidence presented above on the issues speaks for itself for those contemplating variations in the cushioning of housing. To shelter homebuilding during periods of high interest rates means gambling that efficiency and production techniques will be improved significantly by stabilizing housing production or concluding that the effect of housing fluctuations on the supply price of capital and other factors is excessively costly. Yet the federal government already does a great deal to lower the supply price of capital in housing and to support the rate of return in the industry. First and foremost is the national goal to house people properly by building new houses when rehabilitation might well be more efficient. The advantages of aiming credit restriction at housing are substantial, for the industry has many characteristics that make it well 
suited to such a policy. Housing is very durable, has a short production period, and is produced with some factors-primarily labor-that are easily transferred to other industries and with others-primarily lumberthat are capable of substantial downward flexibility in prices. But homebuilding is not unique in these characteristics. In particular, it has no corner on workers with generalized skills adaptable to other industries.

The combination of the structural characteristics that suit homebuilding to the role of reining in aggregate demand with the inflationary impacts of federal programs to shield homebuilding suggests that such programs be used sparingly in the future. Take a situation in which no vigorous fiscal policy is undertaken and in which other spending responds only slowly to changes in market interest rates-and the evidence suggests that this is true for periods of less than a year, the normal horizon of a restrictive monetary policy. In this case, federal mortgage credit programs require that the general level of interest rates be lifted even higher, because the job of restraining housing is larger and housing is the main spending stream that is restrained by interest rate increases over this horizon. It thus appears that caution should be taken in developing new federal programs of support to the mortgage market and in expanding existing programs.

\section{ALLOCATIVE EFFICIENCY}

One key element of federal programs of mortgage market support that would be lost if the scope of programs were reduced is their rationing of funds on the basis of price rather than of nonprice availability considerations. Without these programs, in the short run funds probably do not go to borrowers who are willing to pay most for them, for under the present institutional setup a borrower not only must be willing to pay a high rate but also must have a customer relationship with an institution that happens to have funds to lend. And with present restrictions on institutionsparticularly uniform ceilings on rates on deposits at all members of a class of institutions-there is no incentive for funds to move to institutions patronized by borrowers willing to pay high rates. Therefore funds tend not to be put to their most productive uses.

Federal credit programs are not, however, the only way of eliminating the inefficiencies of nonprice rationing of mortgage funds. In particular, the present system of financial institutions could be changed to enable the demands for funds on the part of borrowers to be transmitted to demands for 
funds by institutions that make mortgage loans. On the most obvious level, mortgage lenders need to be free to pay market yields on their liabilities so that they can hold and enlarge their deposits when market rates rise. In order to be able to pay the higher rates, these institutions need greater flexibility in the kinds of assets they may hold and liabilities they may offer. Such a restructuring of the financial system is obviously a complex undertaking. It has, however, been given comprehensive study by the Hunt Commission $^{42}$ and the administration, and the President has proposed a package of changes to improve the functioning of the financial system..$^{43}$ Adoption of such a set of modifications would improve the allocative efficiency of the financial system by ensuring that funds were put to their most productive uses.

Such a method of improving allocative efficiency without subsidy might still interfere in a modest way with the effectiveness of monetary policy. It would do so to the extent that the impact of monetary policy now comes from intense nonprice factors. If mortgage lenders were permitted to pay higher rates for funds when market rates rose, the availability constraint would be less effective, and the impact of higher rates would work through price rationing for borrowers alone. This might mean that interest rates would have to rise further to produce a given amount of spending restraint. And to the extent that FNMA purchases have such a quick impact on homebuilding because the availability constraint is so binding for building, the response of residential construction might also be retarded, delaying the impact of monetary policy on spending. But the present effects of interest rates on mortgages are not absolutely required in full form for policy effectiveness, and it can be persuasively argued that a change that brought about allocative efficiency in the lending market and more equitable treatment of the mortgage market and homebuilding would be worthwhile. If present trends are any indication, the alternative seems to be increasing federal domination of mortgage lending and the bond market.

42. Report of the President's Commission on Financial Structure and Regulation (1971):

43. See Recommendations for Change in the U.S. Financial System. 


\section{Comments and Discussion}

John Kareken: William Gibson offers his readers some justification for limited federal intervention in the mortgage market; I do not find his rationale for that intervention very convincing, and I am even less sympathetic than he is to the case made by the housing lobby. I am not impressed by the externalities of housing services except perhaps for families with very low incomes.

As far as I am concerned, the high interest elasticity of housing is a fact of life. Together with the forces of cyclical instability, it may make for higher supply prices in the housing industry. To the extent that is true, it is an interesting fact; but it does not have obvious policy implications. Aid for housing is likely to come at the expense of stability in other sectors; a dispersal of the cyclical adjustment burden would probably cause higher supply prices in other sectors. If the disruptions of cyclical instability have to be concentrated in one sector, housing is an acceptable target. Most economists, including Gibson, seem to regard it as self-evident that when market interest rates rise sharply, excess demand for mortgages develops: the mortgage market does not clear and it stays out of balance with excess demand. That assumption may be true, but I would certainly like to see some evidence to support it. It is a crucial assumption: If excess demand does not develop, there is no case for the federal government to ensure the availability of credit at market rates of interest. Without such evidence, I hold a weak presumption that the observations of declining volume in the mortgage market reflect the negative slope of the demand curve rather than excess demand. Or, more accurately, the observations may reflect the response of mortgage demand curves to a number of credit variables, including other features of the complex mortgage contract as well as interest rates.

The whole range of regulations and rules that affect the supply of mortgages gives some presumption that the supply of such funds may be de- 
pressed in periods of tight money. If that is the case, it would offer some justification for federal credit programs in the mortgage market to offset the influence of the federal rules and regulations. If the federal government attempts to undo the problem that it creates, there ought to be a thorough appraisal of just how the rules and regulations operate and what influences they have. Such an appraisal may lead to changing some of the rules and regulations or, alternatively, it may argue for some subsidy to the housing industry through federal credit programs. And if a subsidy is to be provided, it is by no means clear in theory that every federal credit program will in fact increase the stock of housing. Some further analysis is needed of the effects of open market purchases of mortgages, direct lending by the federal government, and government guarantees of mortgages, to determine whether and to what extent they do have that effect.

In my judgment, the real limit to the potency of monetary policy is the unwillingness of our society to accept the failure of lots of financial firms. The reason for changing institutional arrangements is not to protect housing but rather to reduce substantially the risk of financial failure and thereby remove that constraint, although I regard it as a relatively weak one even today. The alternative of using fiscal policy is virtually dismissed by Gibson. It seems to me that those people who are so terribly troubled by the impact of monetary restraint on housing ought to be mobilized into an exceedingly effective lobby for promoting a more flexible fiscal policy. So far, however, no such lobby has developed.

As a final comment, I had difficulty following Gibson's analysis of priceearnings ratios of the homebuilders. It seems to me that a comparison of these price-earnings ratios with those of firms in other industries should answer the question of whether the supply price of capital is in fact higher for homebuilding. I'm not sure why these ratios have to be explained and how the regressions presented in the paper really answer any relevant question. In any case, I would have expected that any higher supply price for capital would apply to the small builders who have greater problems of surviving adversity and fewer options, rather than to sizable corporations with publicly traded stock.

Barry Bosworth: This paper is a good summary of the issues surrounding the use of monetary policy for stabilization purposes. Gibson's work is intended to refine our approach to policy formulation rather than to reach definitive conclusions on policy choices. 
My major criticism is that Gibson has stated the issue too bluntly, in absolute rather than relative terms. The real issue is not whether homebuilding should be protected but rather how much it should be protected relative to other sectors in the economy. Furthermore, Gibson explores inadequately the important issue of the feasibility of spreading the burden of cyclical adjustment more broadly throughout the economy.

I do not favor using the housing industry as a target for stabilization policy, but my objection is primarily an objection to relying heavily on monetary policy as the main tool of stabilization. Given the short time span, that countercyclical policy decisions are meant to influence, I think that most other sectors would be inappropriate targets of credit restraint. Monetary policy has an impact on other activities, such as consumption and business investment, but only over a time horizon of a year or more. For the practical purposes of short-run stabilization policy, the impact on housing is the impact of tight money.

Empirical evidence seems to support Gibson's finding of substantial mobility and substitutability of construction labor. However, neither the construction industry nor its supplying industries are heavily labor intensive so that is not a decisive argument. Moreover, the high levels of seasonal unemployment in construction.labor warn that the mobility of workers is far from perfect in the very short run. Finally, nearly every industry displays the same high degree of mobility, so there is no reason to prefer that the adjustment be centered in housing.

With regard to material inputs, however, housing could be judged one of the industries offering the poorest opportunities for substitution. Many of its material inputs are highly specific and have no good alternative use (softwood offers the prime example). The ups and downs of housing generate recurring bottlenecks in supplying industries. Once these industries cancel their capacity expansion, it may take them several years to return to their previous levels. For example, the capacity of the lumber industry in 1973 was not significantly above that of 1965 .

On the demand side, I question Gibson's emphasis on the small ratio of housing cutbacks to the housing stock. That is not a good criterion for picking the sector that should cushion the blows of economic variability. The crucial consideration should be the utility loss resulting from the deferred consumption and not the magnitude of the deferred consumption. Almost any durable good would satisfy Gibson's criterion-automobiles, for example. Incidentally, automobiles would rank far higher than housing in having a short production period. 
The massive cutbacks in the housing industry would not be deplorable if they reflected consumer choice. But, in the context of imperfect and highly regulated markets, the big fluctuations cannot be read as the verdict of the price mechanism. I cannot share Kareken's agnosticism on this issue. It is a problem, and no amount of financial reform can solve it. Access to capital markets is bound to be better for large corporations than for homebuyers.

Gibson's analysis of price-earnings ratios puzzles me. First of all, I do not understand the theory of capital markets underlying his test. Second, I am unhappy about the use of the square of the variables as a measure of sectoral instability when all of the variables have trends in them. The sector with the largest trend will tend to emerge as the most unstable and this is not the relevant concept of instability. Third, the data period from 1969:1 to 1973:3 is too short to yield any firm conclusions about sectoral variability. Furthermore, the period is dominated by the recovery from the 1969 housing slump and thus does not provide appropriate evidence for judging sectoral instability.

Even more seriously, the supply price of capital is a minor part of the effect of risk on an industry. Industries with highly variable demand may be led to high-cost production techniques. They will opt for flat average cost curves in preference to more steeply sloped cost curves with lower minimum cost, in order to maximize the flexibility of the production process. That risk element will not be captured in price-earnings ratios, but it will raise the commodity price.

Finally, and more generally, inflation takes a variety of forms and the appropriate policy remedies are different depending on the form. The economy needed a moderate amount of monetary restraint in 1973, with an inevitable impact on housing; indeed, it should have come sooner. But monetary policy cannot alleviate the problems of fuel and food shortages. Nor can it stop the institutionalized inflation of high wage increases in the industrial sector. It is tempting to react instinctively to any and all inflationary situations-to tighten money and clobber housing-but that temptation must be resisted.

\section{General Discussion}

James Duesenberry commented on several of the issues raised by Gibson's paper. In response to Kareken, he stressed the importance of credit rationing in the home mortgage market. One piece of evidence is that short- 
term interest rates are generally more effective than long rates in explaining housing fluctuations; short rates are a measure of disintermediationwhich in turn determines credit rationing - while the long rates measure the interest cost on mortgages to homebuyers. Duesenberry expanded on Bosworth's comments that the shape of the cost curves for homebuilders may be influenced by variability. That effect on industry costs could potentially be far larger than any increase in the cost of capital due to risk. $\mathrm{He}$ saw an urgent need for investigation of the actual configuration of the cost curves of firms in the housing industry.

Duesenberry also stressed that the loss of utility associated with a relatively small cutback of the housing stock could be very large, because the impact is so uneven, falling primarily on the small fraction of individuals whose housing needs change as a result of changing family status or job locations.

On the question of labor mobility, Duesenberry suggested that the high mobility of construction workers may result from the cyclical (and seasonal) variability of the industry. He felt that a reduction in the cyclical variability of employment in the construction industry might lower labor costs in two ways: first, by permitting the development of a more stable and more highly skilled labor force; and second, by leading to a reduction of the hourly wage, since an extra wage margin would no longer be needed to compensate for the unsteadiness of jobs. Richard Freeman and Michael Wachter elaborated on the labor mobility issue, insisting that Gibson's statistical findings did not demonstrate that job shifts were costless. For one thing, the transfer might be to lower-paying and less productive jobs.

Robert Solow was not certain of the benefits of resource mobility in a sector restrained by anti-inflationary monetary policy. On some views of the determinants of inflation, the stabilization gain would be greatest if the resources remained idle. Solow also warned that simple regression analysis could not distinguish between the elements of credit rationing and the interest responsiveness of demand. Since availability was likely to be low when interest rates were high, an interest rate variable would pick up some of the effects of rationing. It would thus overstate the responsiveness of demand to the interest rate.

Joseph Pechman expressed concern about the efficiency implications of a fluctuating housing industry. To the extent that the variability of the industry was attributable to the regulations governing financial institutions, a direct effort to reform the regulations seemed more appropriate than at- 
tempts to offset their effects. Pechman felt that Gibson's paper made the case for discretionary fiscal policy and against heavy reliance on monetary policy, although he conceded the political difficulty of implementing appropriate countercyclical fiscal policy.

Henry Aaron wondered whether there was any way to assess the relative importance of institutional constraints and of the high interest elasticity of demand as factors in the variability of the housing industry. In response, Daniel Brill suggested that some clues might be obtained from a study of the mobile home market, which now constitutes about one-fourth of the total housing market (in terms of units). Mobile homes are financed very differently from conventional homes, with greater freedom from interest rate ceilings. Most of the financing institutions operate on a nationwide basis, in sharp contrast to the relatively small and geographically limited savings and loans. Most importantly, the interest rates have moved up rapidly enough to keep these institutions lending in the mobile home market, despite other opportunities. Brill inferred from the cyclical experience of mobile homes that the institutional restraints peculiar to conventional homes were a key element in their variability.

Franco Modigliani commented on the cyclical interdependence of the housing industry and the overall economy. Variability in housing, arising from the use of monetary policy, was necessary to compensate for instability in the overall economy that came about through such disturbances as wars and swings in business investment. The housing industry would be more stable if the overall economy became less variable, since the burden of cyclical adjustment would be lessened. Meanwhile, he felt, the ease of shifting resources from residential to nonresidential construction, if confirmed, would be one of the better arguments for squeezing housing in boom periods.

Modigliani mentioned that index-linked mortgages, a subject of his current research, would provide a mechanism for assisting the housing industry. Under traditional mortgages, when inflationary expectations cause nominal interest rates to rise, the initial payments for a contract are raised in real terms, with the real value of the payments declining in subsequent years. This scheme of payment tends to depress housing demand, particularly discouraging young homebuyers whose incomes tend to be low but rising. With index-linked mortgages, annual payments would be a constant fraction of the principal and the principal would be revalued at regular intervals on the basis of a general price index. In real terms, the annual 
payments would be constant; inflation would be reflected in rising nominal payments. This device would, therefore, insulate the demand for housing from variations in nominal rates resulting from inflationary expectations. Similarly, financial intermediaries making index-linked mortgages could, in turn, offer index-linked deposits (or insurance contracts) which would have great appeal for investors, especially small ones, and could stand the competition of inflation-induced high nominal rates, enhancing the cyclical stability in the supply of mortgage funds to the housing market.

William Poole mentioned his research on index-linked mortgages, which led him to share Modigliani's enthusiasm for the proposal. Poole also commented skeptically on the alleged externalities of homeownership, particularly in light of the recent expansion of condominiums. To the extent that the social benefits of homeownership were important, they argued for measures different from those actually adopted-for example, a flat tax credit for every homeowning household, rather than mortgage interest deductions. In conclusion, Poole added that recent periods of monetary restraint and subsequent housing declines in 1966, 1969, and 1973 had been preceded by excessively easy monetary policy. More even policy might reduce the instability of residential construction.

Arnold Packer observed that one reason that housing was not an ideal sector to absorb the variability of the economy was its small size, amounting to only about 4 percent of GNP. Robert Gordon added that, although it would be desirable to spread the impact of restraint across the economy, resource immobility often made this extremely difficult.

David Fand called attention to the policy statement on housing by the Committee for Economic Development, cited by Gibson. It claimed that as many as one out of seven households in the United States might have inadequate housing. Fand pointed out that inadequate housing was attributable both to low incomes and to imperfect credit markets. He suggested that some portion of federal assistance might be better spent in renovating existing structures and providing an income allowance to encourage housing maintenance and upkeep than in supporting construction of new homes.

Gibson responded briefly to the comments that had been made by others. He observed that an important assumption underlying his work was that the demand for housing cut back by monetary restraint would not shift into other sectors, although the resources freed by the cutback might well shift. He explained that his analysis of price-earnings ratios had been exploratory. It had to be based on an unreasonably short period of observation be- 
cause the necessary data were not available for earlier periods. He also concurred with Bosworth on the importance of risk factors in the choice of production techniques; price-earnings ratios were only one aspect of the overall incorporation of risk. Gibson observed that he had tried to focus his paper on the dominant issues of the domestic mortgage situation, and had omitted references to policies in other countries and to new proposals like index-linked mortgages because they were beyond the scope of this particular paper. 